\title{
Evaluation of in vitro Effect of Pyocyanine Pigment on Interleukin-2 Secretion from Peripheral Blood Mononuclear Cells in Cancer Patients
}

\author{
Anahita Mohseni $^{1}$ (D), Afsoon Shariat ${ }^{* 1}$ (iD \\ 1. Department of Microbiology, School of Basic Sciences, Kazerun Branch, Islamic Azad University, Kazerun, Iran
}

\section{ABSTRACT}

Background and Aim: The pyocyanine pigment in Pseudomonas aeruginosa stimulates blood cells to secrete IL-2. IL-2 cytokine is an activator of cytotoxic T cells and natural killer cells. These cells destroy the target cells of patients with cancer. This study aimed to evaluate the effects of pyocyanine on the IL-2 secretion from peripheral blood mononuclear cells (PBMCs) in patients with breast, prostate, and bladder cancers.

Materials and Methods: : In this cross-sectional descriptive study, a total of 30 P. aeruginosa isolates were collected from different clinical specimens (urine, blood, burns, etc.) of patients admitted to Namazi Hospital in Shiraz, Iran, from October to December 2019. The pyocyanine was extracted from the isolates by chloroform. Also, twenty-eight peripheral blood samples were selected from 21 patients with breast, prostate, and bladder cancers and 7 healthy controls. Following the isolation of PBMCs from patients and the control group using Ficoll density gradient, samples were prepared for cell culture. Half of the PBMCs were treated with pyocyanine $(0.5 \mu \mathrm{g} / \mathrm{mL})$, and the rest of them remained without treatment. Then, the IL-2 secretion from the treated and untreated cells with pyocyanine was investigated by ELISA method. Statistical analysis was done using SPSS 22.

Results: Significant increases were seen in the IL-2 secretion from PBMCs in the patients with breast $(P=0.032)$, prostate $(P=0.002)$, bladder $(P=0.009)$ cancers, and healthy controls $(P=0.004)$ after treatment with pyocyanine in comparing with before treatment with this pigment in vitro.

Conclusion: Low concentrations of pyocyanine can stimulate the PBMC of cancer patients to secrete IL-2 cytokines. Further studies should be performed on the immunostimulatory effects of pyocyanine in laboratory animals.

Keywords: Cancer, Immunostimulant, Pyocyanine, Interleukin-2

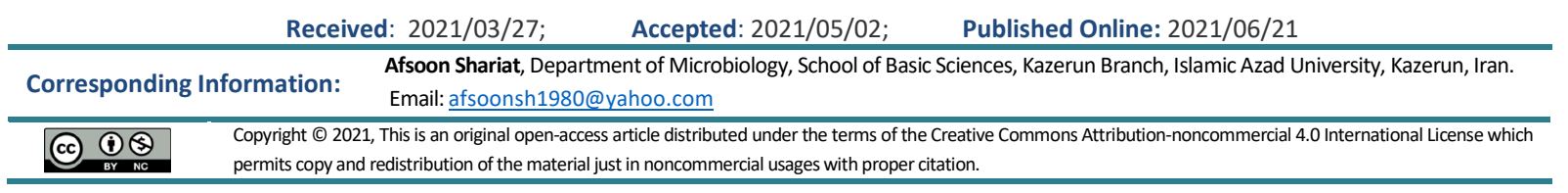

Use your device to scan and read the article online

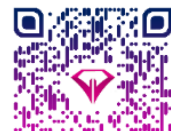

口ilition

Mohseni A, Shariat A,. Evaluation of in vitro Effect of Pyocyanine Pigment on Interleukin-2 Secretion from Peripheral Blood Mononuclear Cells in Cancer Patients. Iran J Med Microbiol. 2021; 15 (3) 327344

Download citation: BibTeX | RIS | EndNote | Medlars | ProCite | Reference Manager | RefWorks

Send citation to: $\Theta_{\text {Mendeley }} \boldsymbol{Z}_{\text {Zotero }} \mathbb{H}_{\text {RefWorks }}$

\section{Introduction}

Cancer is a complex disease that affects cells and disrupts the rate of cell proliferation and differentiation $(1,2)$. Usually, a secondary tumor is formed at the time of diagnosis, which is a late diagnosis and is the cause of high cancer mortality (1). In the Middle East, breast cancer accounts for $32 \%$ of cases of women's cancers and is the first cause of women's death aging 40 to 45 years old $(1,3)$. At the same time, prostate cancer is the most common malignant tumor in men. Generally, one in six men will develop prostate cancer in their lifetime (4). Breast cancer and prostate cancer are the most common causes of death in 
Iranian women and men, respectively (5). Also, bladder cancer is a common disease. In men, its incidence is 2 to 2.5 times more than women; how-ever, it is also common in women who smoke (6). Conventional therapies, such as chemotherapy and radiation therapy, have low survival rates due to tumor progression, resistance to treatment, and non-specific treatment of tumors (7). Scientists are trying to use technology to introduce new treatments for cancer. Various applications of bacteria have been investigated so far (7). Natural compounds derived from them (including bacterial pigments) are reported to have anti-cancer and antioxidant activity, and have unique cancer treatment mechanisms (7).

The most important feature of Pseudomonas aeruginosa is the production of the blue-green pigment of pyocyanine (8).

This pigment has an immunostimulatory effect on cancer patients and is related to cell apoptosis having great potential to inhibit cell proliferation. Hence, due to the action of superoxide dismutase and catalase, it generates a large amount of reactive oxygen species (ROS) (7). These results support the cytotoxicity of pyocyanine in cancer cells. These mechanisms have led to better cancer treatment strategies (9). Also, the pyocyanine has stimulatory activities on IL-2 cytokine such that low concentrations of pyocyanine exacerbated the responses of $T$ lymphocytes (production of IL-2) and B lymphocytes (differentiation to immuneglobulin-producing cells), whereas high concentrations of this pigment had inhibitory effects (10). IL2 is a pro-inflammatory cytokine that is produced in $\mathrm{T}$ cells and participates in the stimulation of immune responses (11). Eventually, since the pyocyanine has immunostimulatory effects and considering that this pigment induces the transcription of inflammatory cytokines and stimulates the secretion of IL-2 from blood cells; the use of the immune system in cancer treatment is a promising approach and it is hoped that with the advancement of studies in this field, a new dimension will be added to cancer treatment $(12,13)$. This study aims to evaluate the ability of different clinical isolates of $P$. aeruginosa to produce pyocyanine and the in vitro immunostimulatory effe-cts of pyocyanine on the IL-2 secretion from PBMCs in patients with breast, prostate, bladder cancers, and healthy control group.

\section{Materials and Methods}

\section{Isolation and Identification of Pseudomonas aeruginosa from Clinical Samples}

In this cross-sectional descriptive study, after approval in the committee for ethics in biomedical research of Kazerun Branch, Islamic Azad University, being presented with the code IR.IAU.KAU.REC-.1399.031, a total of $30 P$. aeruginosa isolates were collected from different clinical specimens such as urine, blood, burn, sputum, and wound infections of patients admitted to Namazi Hospital in Shiraz from October to December 2019. All isolates were identi-fied as $P$. aeruginosa using gram stain and biochemical characterization (14). The isolates were randomly eva-luated to determine the rate of pyocyanine produc-tion. To maintain the bacteria, the strain was inocula-ted in the broth medium of tryptic soy broth (Quelab, Canada) containing glycerol, and then stored at $-70^{\circ} \mathrm{C}$ (15).

\section{Extraction of Pyocyanine from Pseudomonas aeruginosa Isolates}

All bacterial isolates were cultured on Pseudomonas agar culture media (Quelab, Canada), and incubated at $37^{\circ} \mathrm{C}$ for 48 hours. The positive isolates in the production of pyocyanine showed blue-green pigments. Then, chloroform (Merck, Germany) was poured on the culture medium (1:2 ratio), then vortex (Labinco, Netherlands) vigorously for 1 minute. The culture was centrifuged at $5000 \mathrm{rpm}$ (Hettich, Germany) for 10 minutes, and formed two organic and aqueous phases. The supernatant was separated and pyocyanine was extracted. Then, added $1 \mathrm{~mL}$ of $0.1 \mathrm{M}$ $\mathrm{HCl}$ (Merck, Germany) to observe pink to deep red color. The pigment was purified by repeated addition of the chloroform solvent (16).

Extracted pyocyanine was poured into a watch glass (Schott Duran, Germany) and kept for 24 to $48 \mathrm{~h}$ under a hood (BioBase, Iran) to completely remove chloroform. Finally, the dried pigment was separated by a sterile lancet (Azmaplast, Iran) and stored in the refrigerator in powder form for later stages. The concentration $(\mu \mathrm{g} / \mathrm{mL})$ of the pigment was determined by measuring the optical density at a wavelength of $520 \mathrm{~nm}$ using a spectrophotometer (Unico, USA) $(16,17)$.

\section{Patients and Study Population}

Due to the rapidly increasing prevalence of breast, prostate, and bladder cancers, and the urgent need for their treatment, the sampleas were selected from among the patients diagnosed with these cancers.Twenty-one patients with breast $(n=7)$, prostate $(n=7)$, and bladder $(n=7)$ cancers admitted to the Cancer Center of Shiraz Namazi Hospital were included in this study from August to December 2019. The reason for choosing 7 samples per group was that the number was statistically acceptable. Seven heaIthy volunteers were recruited as a control group. There was no history of cancer in this group. The age range (46-65 years old) and male to female ratio were similar in studied cancer patients and healthy controls. Patient and control groups were matched for age and gender. Five $\mathrm{mL}$ fresh blood was obtained from cancer patients and healthy individuals by venous puncture and collected in sterile tubes containing EDTA. The 
sample was sent to the laboratory for the isolation of peripheral blood mononuclear cells (PBMCs). The specifications of breast, prostate, and bladder cancer patients were shown in table 1.

Table 1. Specifications of breast, prostate, and bladder cancer patients

\begin{tabular}{|c|c|c|c|c|c|}
\hline No. & Sexuality & Age & Family history & Stage & Metastasis \\
\hline \multicolumn{6}{|c|}{ Breast cancer patients $(n=7)$} \\
\hline 1 & Woman & 59 & No & III & Yes \\
\hline 2 & Woman & 53 & No & II & Unknown \\
\hline 3 & Woman & 46 & Yes & 1 & No \\
\hline 4 & Woman & 55 & No & II & Unknown \\
\hline 5 & Woman & 63 & Yes & II & Unknown \\
\hline 6 & Woman & 57 & No & II & Unknown \\
\hline 7 & Woman & 50 & No & II & Unknown \\
\hline \multicolumn{6}{|c|}{ Prostate cancer patients $(n=7)$} \\
\hline 1 & Man & 72 & Yes & III & Unknown \\
\hline 2 & Man & 59 & Yes & II & No \\
\hline 3 & Man & 56 & Yes & II & No \\
\hline 4 & Man & 62 & No & II & No \\
\hline 5 & Man & 70 & No & III & Unknown \\
\hline 6 & Man & 57 & Yes & I & No \\
\hline 7 & Man & 65 & No & 1 & No \\
\hline \multicolumn{6}{|c|}{ Bladder cancer patients $(n=7)$} \\
\hline 1 & Man & 49 & No & 1 & No \\
\hline 2 & Man & 58 & No & I & No \\
\hline 3 & Woman & 60 & No & II & No \\
\hline 4 & Man & 39 & Yes & 1 & No \\
\hline 5 & Man & 44 & Yes & 1 & No \\
\hline 6 & Man & 50 & No & 1 & No \\
\hline 7 & Woman & 45 & Yes & I & No \\
\hline
\end{tabular}

\section{Separation of PBMCs from Patients with Cancer} and Healthy Controls

Separation of PBMCs from patients with cancer and healthy control samples was performed using the ficoll density gradient method (18). The blood sample was transferred to a $50 \mathrm{~mL}$ tube and diluted 1:1 ratio with PBS (Merck, Germany). Then, diluted blood samples were slowly added to the Ficoll (Inno-Train, Germany). The samples were centrifuged at $400 \mathrm{rpm}$ for 20 minutes at $20^{\circ} \mathrm{C}$ (Hettich, Germany). The PBMCs (cloudy layer) were collected from the diluted plasma/ficoll interface using a serological pipette and the cells were placed into a sterile $50 \mathrm{~mL}$ tube. Again, the cells were washed by adding PBS and centrifuged at $330 \mathrm{rpm}$ for 10 minutes (19).

\section{Cultures of PBMCs Isolated from Patients with} Cancer and Healthy Controls

After the separation was performed, $100 \mu \mathrm{L}$ PBMCs isolated from the patients with cancer and the healthy control group was transferred to a $25 \mathrm{~cm}^{2}$ flask
(Jetbiofil, Canada) containing RPMI 1640 medium (Biosera, France) and 20\% fetal bovine serum (FBS) (Biosera, France). The flask was placed in a $5 \% \mathrm{CO}_{2}$ incubator (Lab Tech, South Korea) at $37^{\circ} \mathrm{C}$ and $98 \%$ humidity. After 48 hours, the culture medium was replaced and the cells were passaged (20).

In order to harvest the cells attached to the bottom of the flask, the medium was washed thoroughly and slowly with PBS. Then, added the trypsin enzyme (Merck, Germany) to the flask and placed in the incubator at $37^{\circ} \mathrm{C}$ for 2 to 5 minutes. After pipetting, the cells isolated from the flask floor were transferred to a $15 \mathrm{~mL}$ sterile falcon tube. The tube containing the cells was centrifuged for about 5 minutes at $1200 \mathrm{rpm}$. The supernatant was evacuated to the cells and the new medium was added. The cell suspension was split into several new flasks. $20 \mu \mathrm{L}$ cell suspension was mixed with $20 \mu \mathrm{L}$ trypan blue (Sigma, USA). Then, live cells (cells that do not penetrate the color) were counted in the 25th hemocytometer (HBG, Germany) (20). 
Effect of Pyocyanine on the Secretion of IL-2 from PBMCs of Patient and Control Groups

Half of the PBMCs of cancer patients and healthy controls were treated with pyocyanine $(0.5 \mu \mathrm{g} / \mathrm{mL})$, and the rest of them remained without treatment. Then, the supernatants were removed and the concentration of IL-2 was determined by ELISA using a commercial human IL-2 ELISA kit (Thermo Fisher Scientific, Australia), according to the manufacturer's instructions.

\section{Statistical Analysis}

The secretion of IL-2 from the treated and untreated cells with pyocyanine was compared by paired sample's T-test. Also, statistical analysis of the samples was done using SPSS version 22 (SPSS Inc., Chicago, IL., USA). All results were expressed as mean \pm standard error (SE). A p-value of 0.05 or less was considered statistically significant.

\section{Results}

\section{Selection of the Highest Pyocyanine Producer Isolate}

Among clinical isolates, isolate 11 (from a wound source) was the highest pyocyanine-producing agent, and this isolate was used for testing in the same sample. Table 2 shows the concentrations of pyocyanine produced by Pseudomonas aeruginosa isolates.

Table 2. The concentrations of pyocyanine produced by $P$. aeruginosa isolates

\begin{tabular}{|c|c|c|c|}
\hline No. Isolates & Source & OD & Concentration of pyocyanine $(\mu \mathrm{g} / \mathrm{mL})$ \\
\hline 1 & Urine & 0.20 & 3.41 \\
\hline 2 & Urine & 0.19 & 3.24 \\
\hline 3 & Wound & 0.08 & 1.36 \\
\hline 4 & Blood & 0.42 & 7.17 \\
\hline 5 & Urine & 0.10 & 1.70 \\
\hline 6 & Burn & 0.17 & 2.90 \\
\hline 7 & Burn & 0.21 & 3.58 \\
\hline 8 & Blood & 0.27 & 4.60 \\
\hline 9 & Blood & 0.34 & 5.80 \\
\hline 10 & Blood & 0.19 & 3.24 \\
\hline 11 & Wound & 0.58 & 9.90 \\
\hline 12 & Urine & 0.06 & 1.02 \\
\hline 13 & Urine & 0.20 & 3.41 \\
\hline 14 & Blood & 0.46 & 7.85 \\
\hline 15 & Burn & 0.55 & 9.38 \\
\hline 16 & Urine & 0.30 & 5.12 \\
\hline 17 & Sputum & 0.07 & 1.19 \\
\hline 18 & Wound & 0.09 & 1.53 \\
\hline 19 & Blood & 0.33 & 5.63 \\
\hline 20 & Urine & 0.40 & 6.82 \\
\hline 21 & Urine & 0.07 & 1.19 \\
\hline 22 & Blood & 0.45 & 7.68 \\
\hline 23 & Blood & 0.17 & 2.90 \\
\hline 24 & Urine & 0.08 & 1.36 \\
\hline 25 & Sputum & 0.09 & 1.53 \\
\hline 26 & Burn & 0.46 & 7.85 \\
\hline 27 & Urine & 0.39 & 6.65 \\
\hline 28 & Sputum & 0.33 & 5.63 \\
\hline 29 & Blood & 0.13 & 2.21 \\
\hline 30 & Urine & 0.45 & 7.68 \\
\hline
\end{tabular}


Comparison of IL-2 Secretion from PBMCs of Patients and Control Groups Before and After Treatment with Pyocyanine

The ELISA method was used to compare the secretion levels of IL-2 in PBMCs of cancer patients $(n=21)$ and healthy control samples $(n=7)$ before and after treatment with pyocyanine pigment (Figures 14). In all groups, after treatment with pyocyanine, the secretion level of IL-2 of PBMC was higher than that of pretreatment with this pigment.

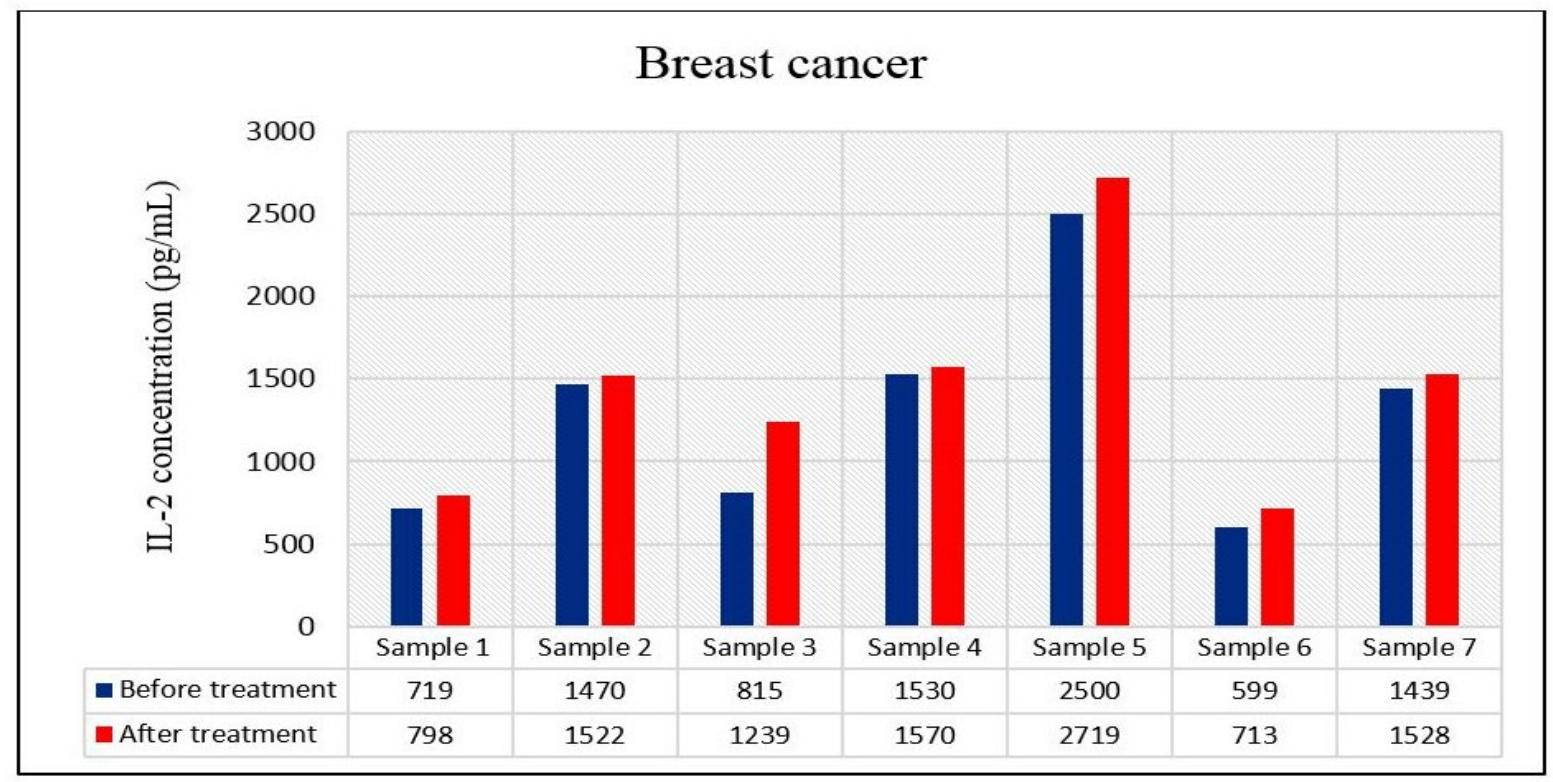

Figure 1. IL-2 production from PBMCs of breast cancer patients $(n=7)$ before and after treatment with pyocyanine

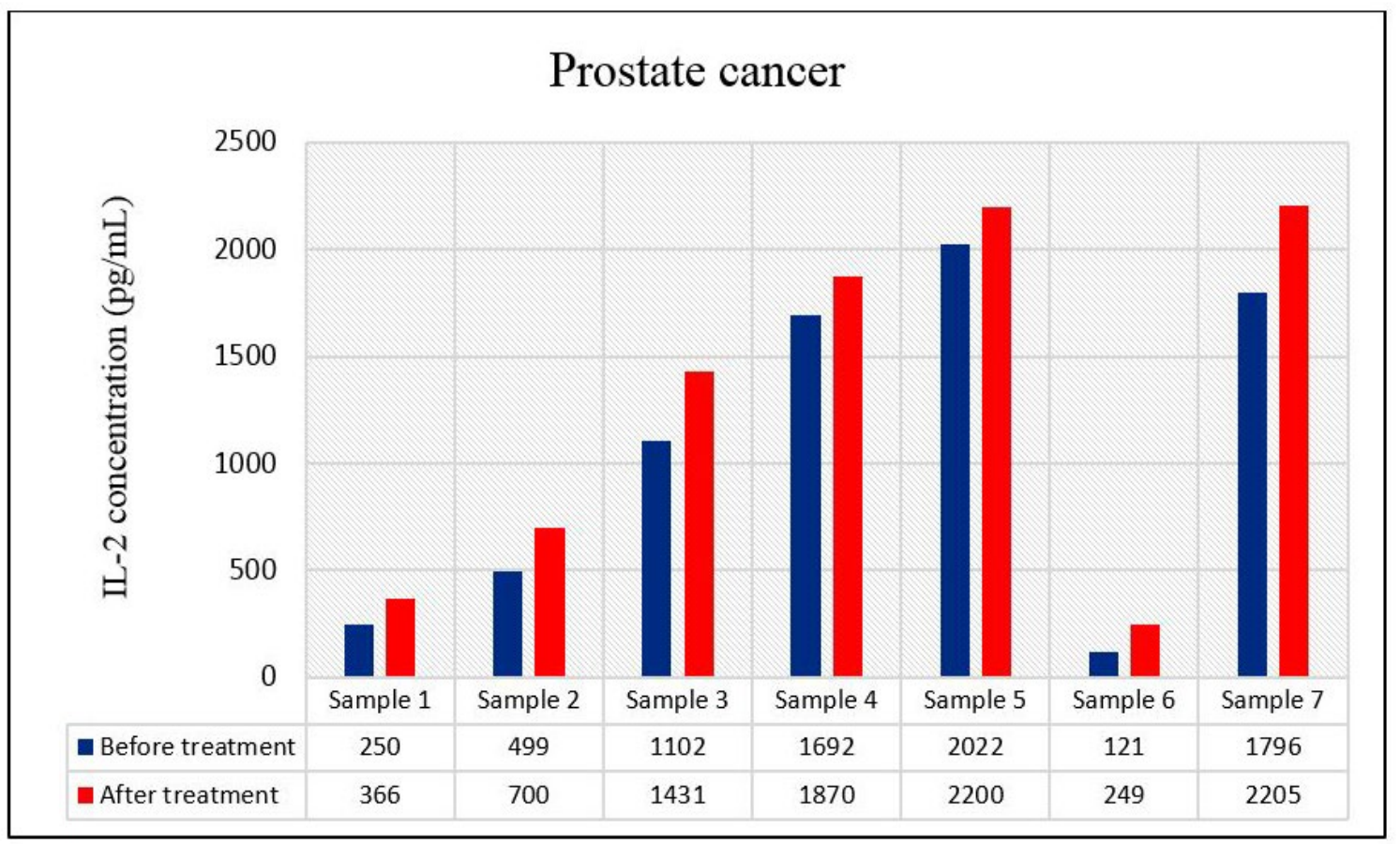

Figure 2. IL-2 production from PBMCs of prostate cancer patients $(n=7)$ before and after treatment with pyocyanine 


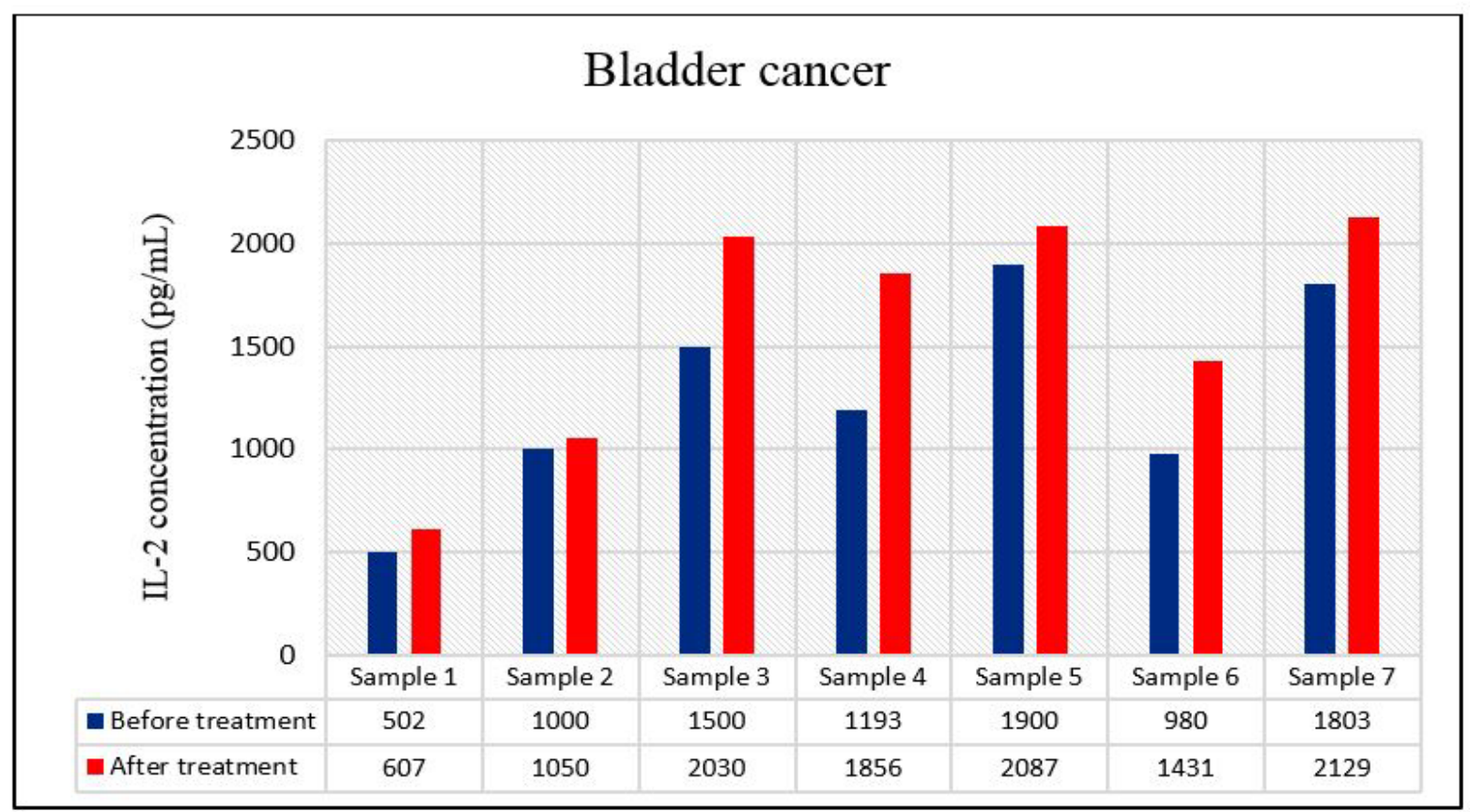

Figure 3. IL-2 production from PBMCs of bladder cancer patients $(n=7)$ before and after treatment with pyocyanine

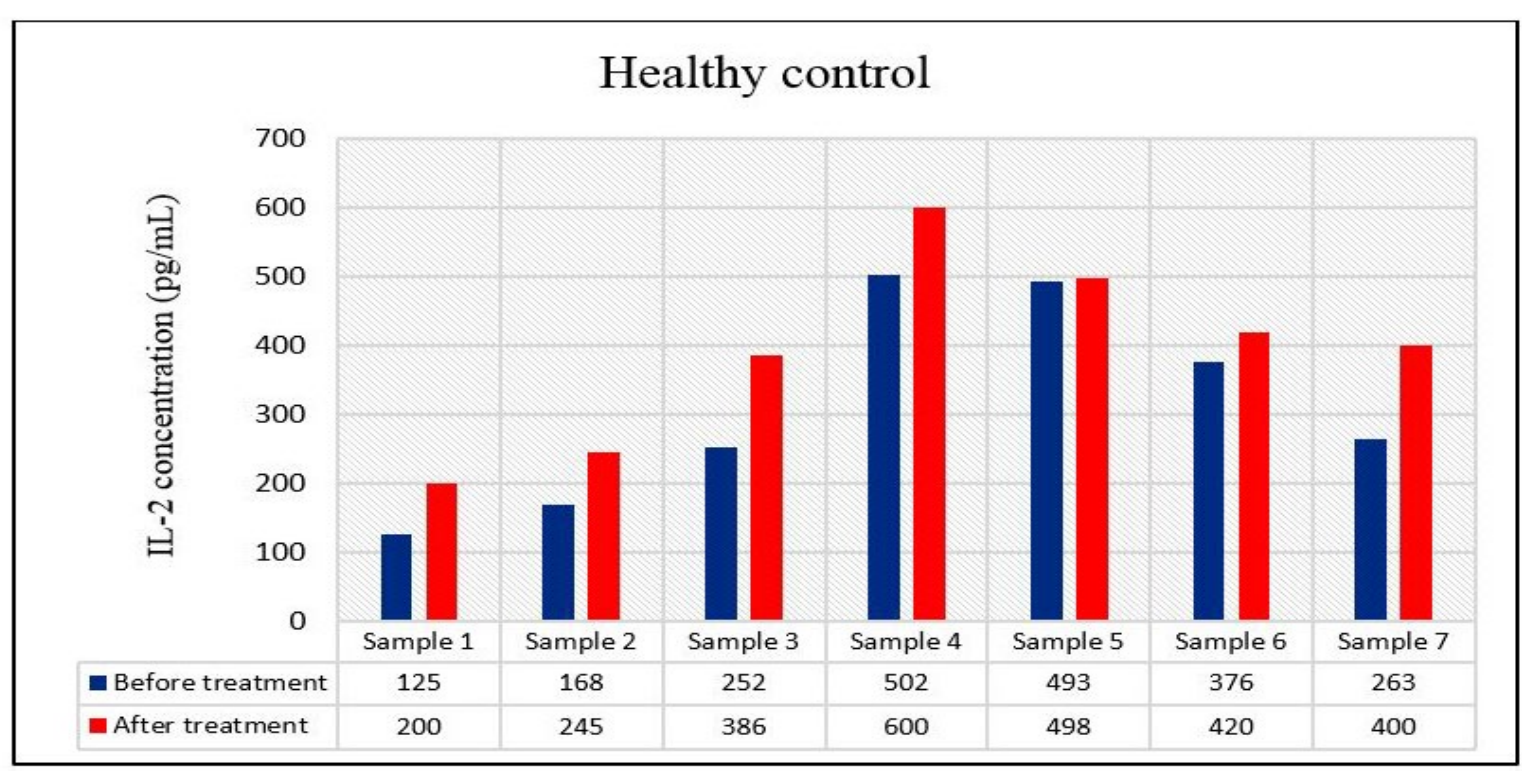

Figure 4. IL-2 production from PBMCs of healthy individuals $(n=7)$ before and after treatment with pyocyanine

The secretion of IL-2 from PBMCs of breast cancer patients was significantly increased after treatment with pyocyanine in comparison with before treatment with this pigment with a mean of $1440 \pm 252.2 \mathrm{pg} / \mathrm{mL}$ vs $1296 \pm 246.56 \mathrm{pg} / \mathrm{mL}(P=0.032)$ (Figure 5$)$.

The secretion of IL-2 from PBMCs of prostate cancer patients was significantly higher in the treated cells with pyocyanine than that in untreated cells with this pigment with a mean of $1288.71 \pm 320.93 \mathrm{pg} / \mathrm{mL}$ vs $1068.86 \pm 298.27 \mathrm{pg} / \mathrm{mL}(P=0.002)$ (Figure 5) .
The IL-2 secretion level from PBMCs of bladder cancer patients was significantly increased after treatment with pyocyanine in comparison with before treatment with this pigment with a mean of $1598.57 \pm$ $223.26 \mathrm{pg} / \mathrm{mL}$ vs $1268.29 \pm 188.54 \mathrm{pg} / \mathrm{mL}(P=0.009)$ (Figure 5).

The secretion of IL-2 from PBMCs of healthy control individuals was significantly higher in the treated cells with pyocyanine than that in untreated cells with this pigment with a mean of $392.71 \pm 52.17 \mathrm{pg} / \mathrm{mL}$ vs $311.29 \pm 56.74 \mathrm{pg} / \mathrm{mL}(P=0.004)$ (Figure 5). 
Therefore, in breast cancer, prostate cancer, bladder cancer, and healthy controls, the increase in IL-2 concentration after treatment with pyocyanine was $11.1 \%, 20.5 \%, 26 \%$, and $26.1 \%$, respectively (Figure 5).

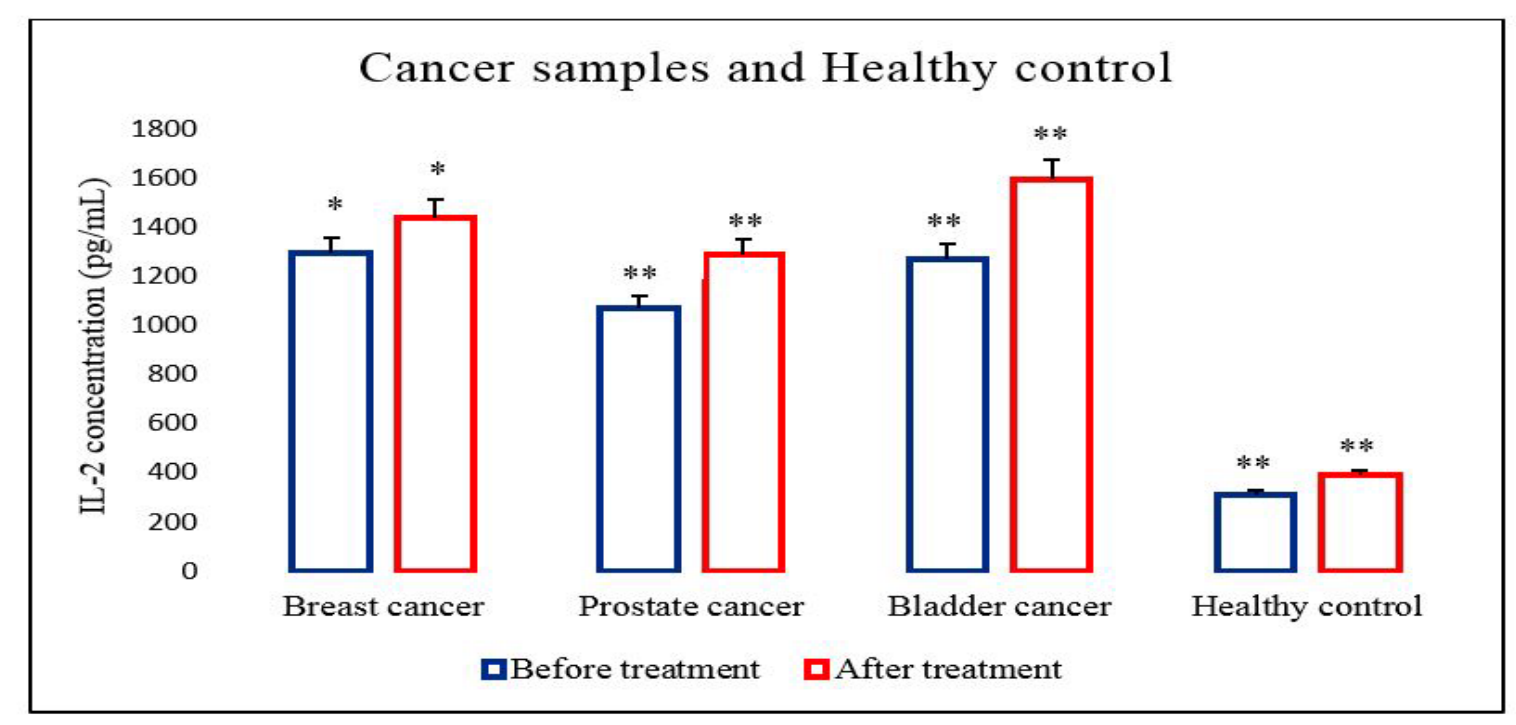

Figure 5. Comparison of IL-2 secretion from PBMCs of cancer samples and healthy control before and after treatment with pyocyanine. $P<0.05(*)$ and $P<0.01(* *)$.

\section{Discussion}

The bacterial pigments have immunostimulatory effects on the immune system by the release of cytokines in cancer patients (21). Despite the importance of the immune system in response to cancer treatment, there has been no report on how to stimulate the immune system with the pyocyanine pigment of Pseudomonas aeruginosa.

Based on the results of this study, a low concentration of pyocyanine stimulates the IL-2 secretion by PBMCs in cancer patients in vitro. Imm-unotherapy using IL-2 is the most effective anti-cancer treatment (12). The mechanism of the action of pyocyanine on IL2 production is still unclear. Pigment probably stimulates the patient's immune system (22). In 2011, research conducted by Rada and colleagues found that pyocyanine can induce the tran-scription of inflammatory cytokines and epider-mal growth factor receptors, as well as IL-1, IL-6, IL-8 cytokines, and TNF $\alpha$ (alpha tumor necrosis factor) (22). Perhaps certain bacterial pigments (such as pyoc-yanine) activate signal transduction pathways through Toll-like receptors (TLR) in PBMC, thereby stimulating the secretion of cytokines including IL-2 (23). The immunostimulatory effect of pyocyanine depends on the concentration of pyocyanine tested (24).

In one study, the inhibitory and stimulating activity of pyocyanine on IL-2 secretion was tested (10). The results were different and the cellular response was related to the concentration of pyocyanine (10). Low concentrations $(0.1,0.2,0.5 \mu \mathrm{g} / \mathrm{mL})$ of pyocyanine will increase the response of $T$ lymphocytes (IL-2 production) and $B$ lymphocytes (differentiation of immunoglobulin-producing cells), while high concentrations of this pigment $(1 \mu \mathrm{g} / \mathrm{mL})$ has an inhibitory effect (10). Similarly, in this study, it was observed that after treatment with a low concentration of pyocyanine $(0.5 \mu \mathrm{g} / \mathrm{mL})$ in vitro, the IL-2 secreted by the PBMC of breast cancer, prostate cancer and bladder cancer patients increased.

IL-2 is an activator of cytotoxic T cells (CTL) and natural killer cells (NK cells) (10). NK cells destroy the target cell by secreting their granules (enzymes and proteins) and designing apoptosis (25). NK cells are transformed into lymphokine-activated killer cells (LAK cells) under the action of IL-2 (25). LAK cells have higher apoptotic activity and can destroy different tumor cells (25).

In studies on the role of IL-2 in cancer treatment, similar studies have been conducted on the positive effects of IL-2 in the recovery and treatment of patients with kidney, breast, prostate, and bladder cancer (26-30). Metastatic melanoma and renal cell carcinoma treated with high-dose Interleukin-2 (30). In advanced melanoma, high-dose IL-2 injection is effective in $15 \%$ to $20 \%$ of patients (30). The patients with metastatic breast cancer were treated with IL-2 and this cytokine increased the number of NK cells and 
cell lysis function in the body (29). Freytag and colleagues demonstrated the IL-2 gene therapy strategy for local and metastatic prostate cancer in 2007 (28). The result was a 50\% reduction in tumors in patients after IL-2 treatment (28). Askeland and colleagues in 2012, showed the function of IL-2 in increasing the NK cells in patients with bladder cancer, and the systemic result of IL-2 in reducing the size of the tumor, tumor growth, and survival time of cancer patients (27). These results indicate that IL-2 has an important role in reducing inflammation in the tumor environment and can have a very positive effect during regular periods, which can indicate a reduction in tumor volume growth. It is recommended in future research, increase the size of the statistical community as much as possible.

\section{Conclusion}

The results of this study indicate that treatment with pyocyanine pigment can increase the IL-2 concentration of PBMCs in patients with breast, prostate, bladder cancer, and healthy controls. Low concentrations of pyocyanine may activate the host's immune response. This pigment stimulates the secretion of IL-2 by activating the TLR signal transduction pathway in PBMC and inducing the transcription of cytokines. With the unique properties of pyocyanine and the human desire for biology and low-risk treatments, we hope that it can broaden our understanding of immunobiology and recognize the immunostimulatory effects of various bacterial pigments on cancer patients. Although this study is the first step to identify the immunostimulatory effects of pigments in vitro, the anti-tumor effects of pyocyanine in experimental animals should be further studied. Also, more efforts are needed to determine the mode of action and the potential of using the pigment in the stimulation of PBMCs in cancer patients for the anti-cancer IL-2 secretion.

\section{Acknowledgment}

This article is the result of a part of the master's thesis of microbiology from the Islamic Azad University, Kazerun Branch. The project was approved by the committee for ethics in biomedical research of Islamic Azad University, Kazerun Branch (IR.IAU.KAU.REC.1399.031). The authors thank all those who helped them writing this article.

\section{Conflict of Interest}

The authors declared no conflict of interests. 


$$
\begin{aligned}
& \text { مجله ميكروبشناسى يزشكى ايران }
\end{aligned}
$$

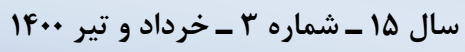

$$
\begin{aligned}
& \text { Journal homepage: www.ijmm.ir }
\end{aligned}
$$

ارزيابى اثر رنكدانه يِيوسيانين بر ترشح اينترلوكين Y از سلولهاى تك هسته خون محيطى

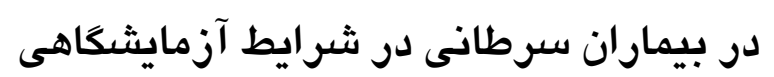

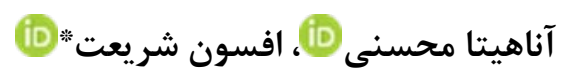

ا. َروه ميكروبيولوزى، دانشكده علوم پايه، واحد كازرون، دانشعاه آزاد اسلامى، كازرون، ايران.

\begin{tabular}{|c|c|}
\hline جكيده & اطلاعات مقاله \\
\hline 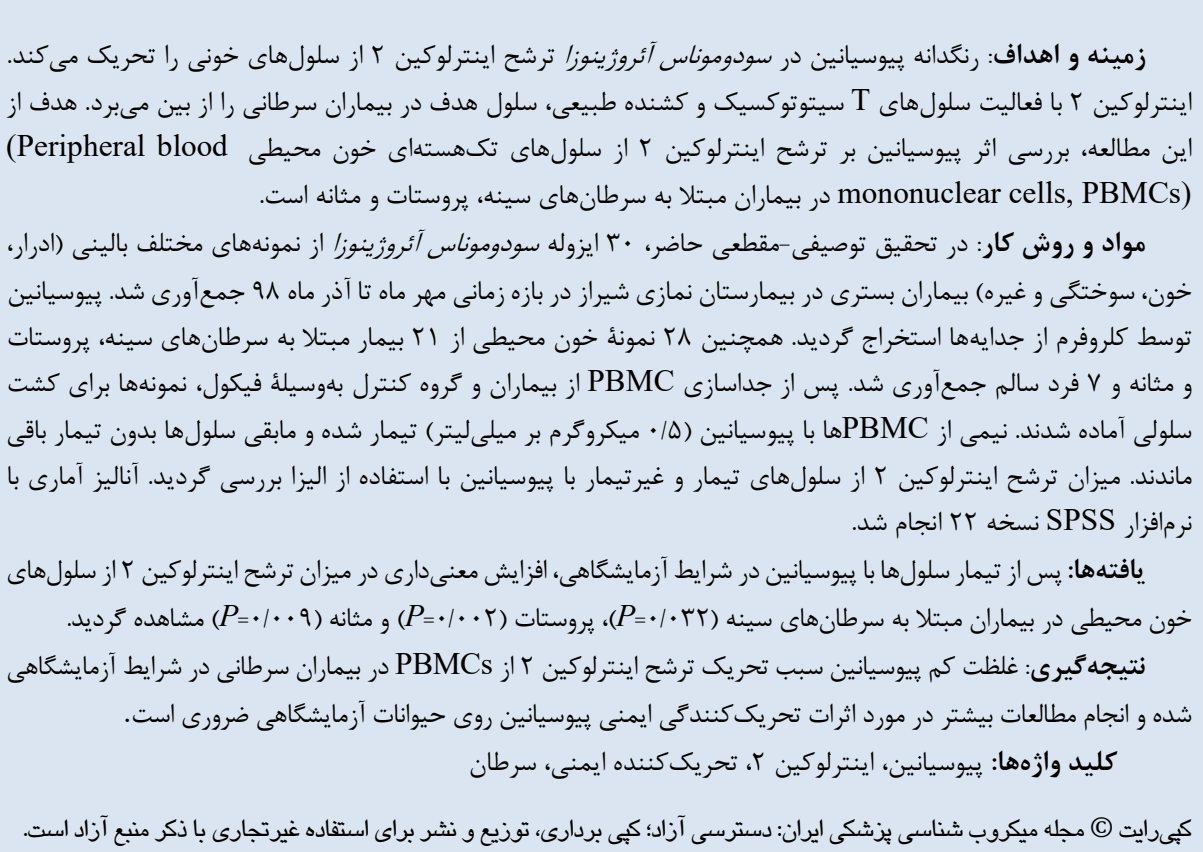 & 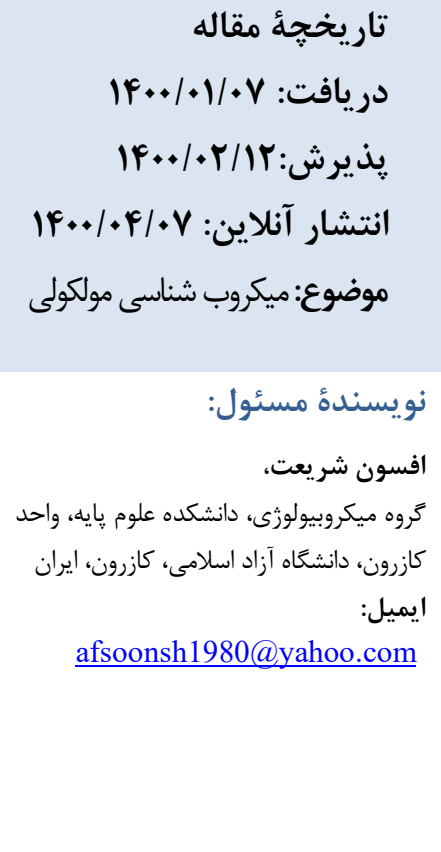 \\
\hline
\end{tabular}

مقدمه

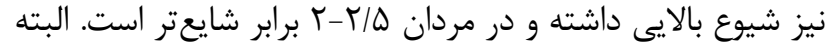

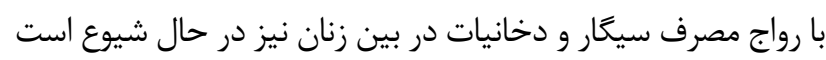
(9). درمانهاى مرسوم مانند شيمىدرمانى و اشعهدرمانى بلهدليل

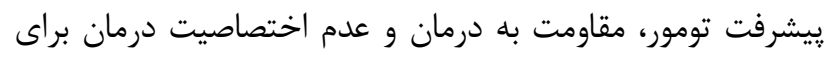

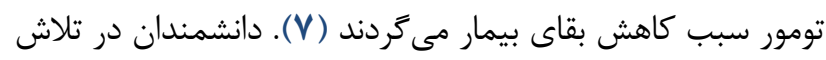

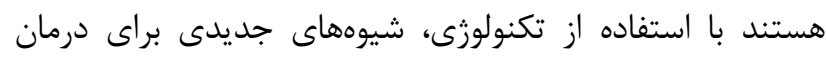
سرطان معرفى كنند؛ در اين راستا، كاربردهاى متنوع باكترىهاي بررسى شده است (V). تركيبات طبيعى مشتقشده از آنها از جمله دانه

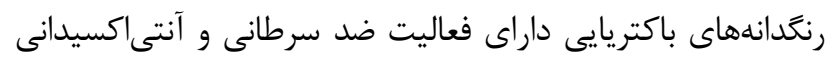

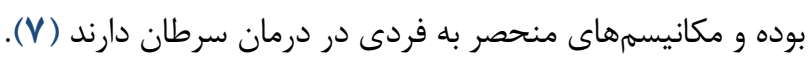

سرطان، بيمارى يِيجيدهاى است كه بر سلول اثر كذاشته و

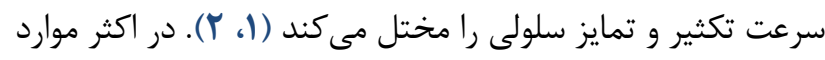

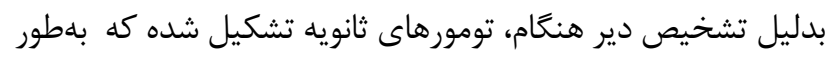

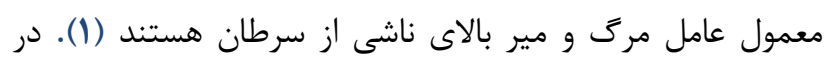

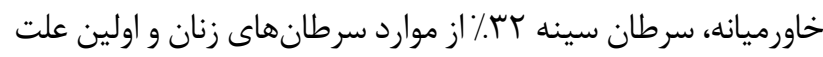

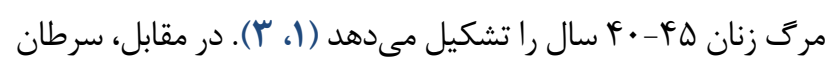

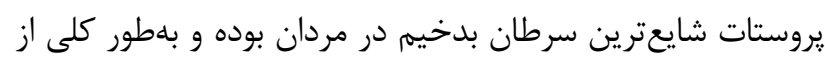

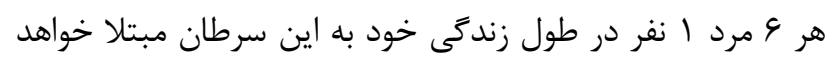

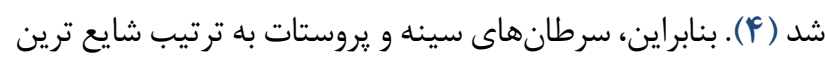

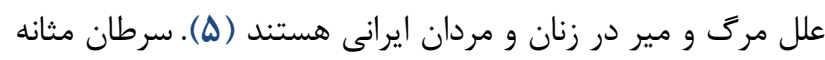


(F) (1) جدايهها بهطور تصادفى جهت تعيين ميزان توليد وييوسيانين مورد ارزيابى قرار كرفتند. سويهها در محيط كشت مايع ترييتيك سوى براث

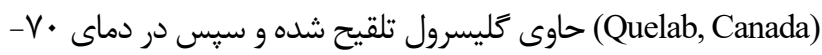
درجه سليسيوس ذخيره گرديدند (ه)().

استخراج ييوسيانين از ايزولههاى سودوموناس

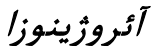

تمام جدايههاى باكتريايى روى محيط كشت سودوموناس آكار كشت داده شدند و به مدت ^^أ ساعت در دماى (Quelab, Canada)

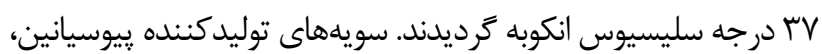

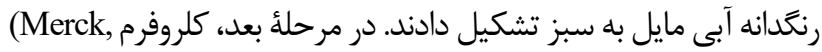

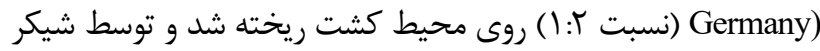
به مدت يك دقيقه به خوبى تكان داده شد. (Labinco, Netherlands)

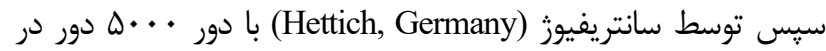

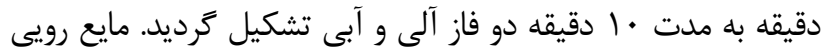

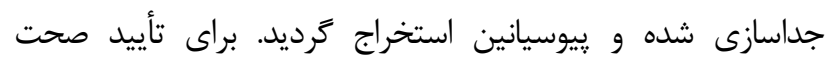

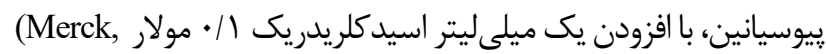
بermany) با افزودن مكرر حلال كلروفرم خالصسازى كرديد (1) (1). سيس بيوسيانين استخراج شده درون يك شيشه ساعت Schott)

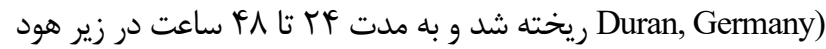
نكمدارى كرديد تا بلهور كامل كلروفرم خارج شود. (BioBase, Iran) سرانجام، رنكدانه خشك شده را توسط يك لانس كانست استريل

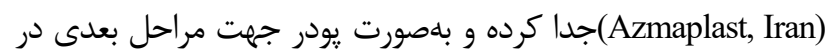
يخجال نتحهدارى گرديد. غلظت رنخدانه بر حسب ميكروگرم بر ميلى

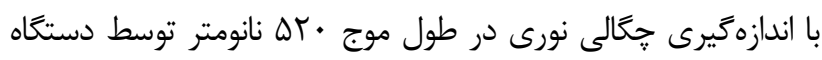

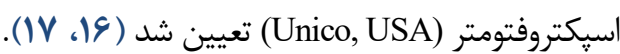

\section{بيماران و جمعيت مورد مطالعه}

به دليل افزايش شيوع سرطانهاى سينه، يروستات و مثانه، و اهميت درمان اين بيمارىها، نمونههاى تحقيق از ميان مبتلايان به اين

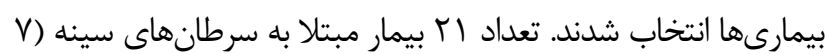
نفر)، يروستات (V نفر) و مثانه (V نفر) بسترى در بخش سرطاب لنان

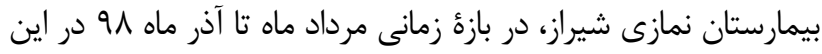

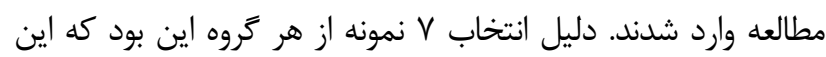
تعداد از نظر آمارى قابل قبول بود. هميجنين، V داوطلب سالم كه سابقه سرطان نداشتند نيز بهعنوان گروه كنترل انتخاب كرديدند. محدوده

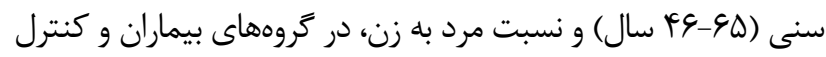

مهمترين ويزگى باكترى سودوموناس آئروزينوزا توليد رنخدانه سبز آبى ييوسيانين است (A). اين رنكدانه داراى اثرات تحريك كنندگى سيستم ايمنى در بيماران سرطانى بوده و با آيويتوز

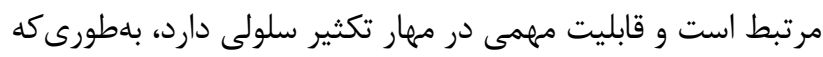
در نتيجه عملكرد آنزيمهاى سويراكسيد دسموتاز و كاتالاز، مقادير داريط

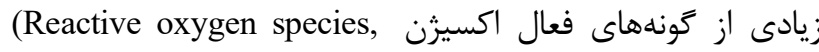

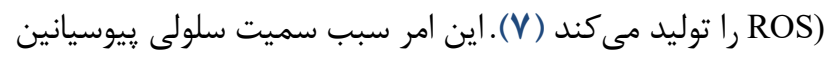

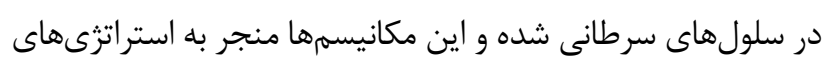
درمانى بهتر در درمان سرطان مى كردند (9). همجنين رنحَدانه ييوسيانين داراى فعاليتهاى تحريكى بر روى ترشح سيتوكين

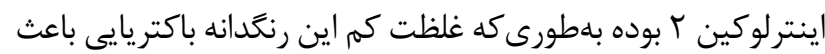

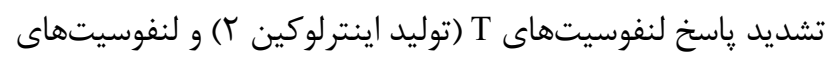
B

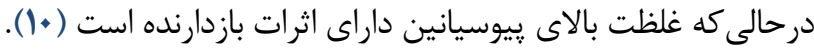

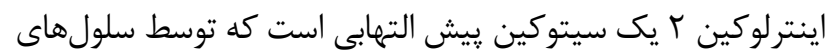
ساخته شده و در تحريك پاسخهاى ايمنى مشاركت دارد (11).

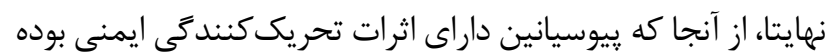
و با توجه به اينكه اين رنكدانه سبب القاى رونويسى از سيتوكينهاى

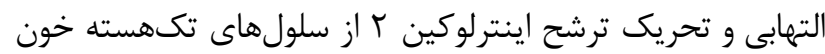

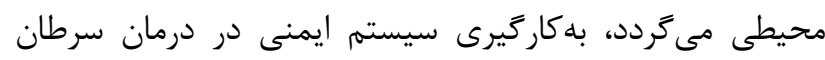

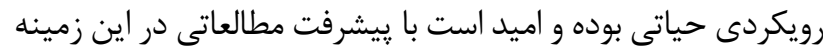
بعد جديدى به درمان سرطان اضافه شود (rا، با). هدف از اين تحقيق، ارزيابى ايزولههاى مختلف بالينى سودوموناس آئروزينوزا

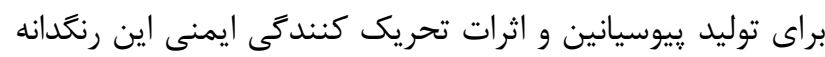

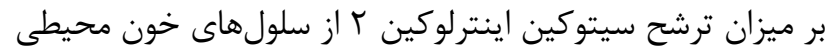
در بيماران مبتلا به سرطانهاى سينه، يروستات، مثانه و گروه كنترل سالم در شرايط آزمايشكاهى است.

مواد و روشها - (- ماد

\section{جداسازى و شناسايى سودوموناس آثروزينوزا از نمونه ناى بالينى}

در اين مطالعه توصيفى -مقطعى، پِ إن از تأييد در كميته اخلاق

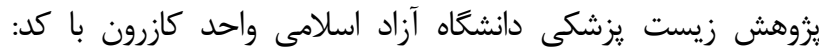

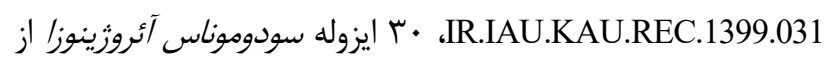

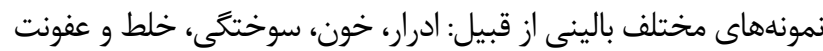
زخم بيماران بسترى در بيمارستان نمازى شيراز در بازه زمانى مهر ماه

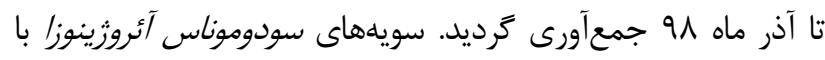
استفاده از رنگَآميزى كرم و خصوصيات بيوشيميايى شناسايى شدند آند 
(Peripheral blood mononuclear cells, تكهستهاى خون محيطى

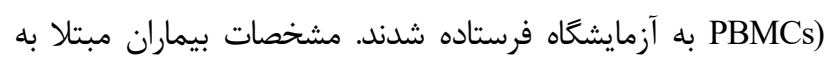
سرطانهاى سينه، يروستات و مثانه در جدول إنشان داده شده است.
سالم مشابه بودند. ه ميلىليتر خون تازه از بيماران مبتلا به سرطان و

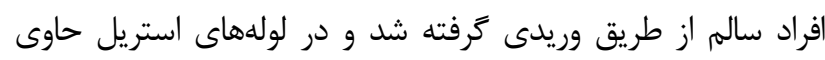

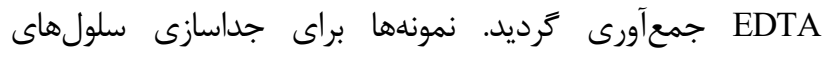

جدول ا. مشخصات دموكرافيك و تاريخِهلى يزشكى نمونهاى سرطانى سينه، بروستات و مثانه

\begin{tabular}{|c|c|c|c|c|c|}
\hline متاستاز & مرحله بيمارى & سابقه خانوادَّى & سن & جنسيت & ايزوله \\
\hline \multicolumn{6}{|c|}{ بيماران سرطان سينه ( لنفر) } \\
\hline بله & III & خير & $\Delta 9$ & 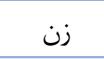 & 1 \\
\hline 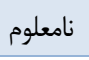 & II & خير & $\Delta r$ & 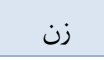 & r \\
\hline خير - & I & بله & kq & 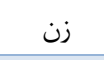 & $r$ \\
\hline 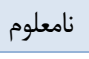 & II & خير & $\Delta \Delta$ & 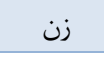 & r \\
\hline 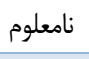 & II & بله & $9^{\mu}$ & 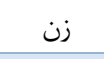 & $\Delta$ \\
\hline 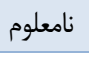 & II & خير & $\Delta V$ & 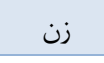 & द \\
\hline 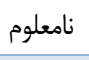 & II & 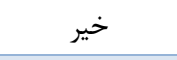 & $\Delta \cdot$ & 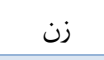 & $v$ \\
\hline \multicolumn{6}{|c|}{ بيماران سرطان يروستات (V نفر) } \\
\hline 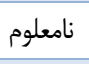 & III & بله & VT & مرد & 1 \\
\hline 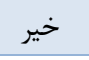 & II & بله & $\Delta 9$ & 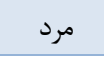 & $r$ \\
\hline خير - & II & بله & $\Delta \varphi$ & 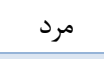 & $r$ \\
\hline خير & II & 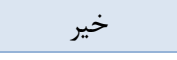 & GT & مرد اد & r \\
\hline 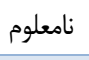 & III & 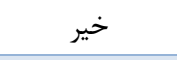 & $\vee \cdot$ & 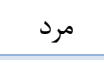 & $\Delta$ \\
\hline خير & I & بله & $\Delta V$ & 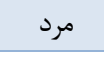 & 9 \\
\hline خير & I & 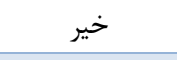 & $9 \Delta$ & 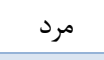 & $v$ \\
\hline \multicolumn{6}{|c|}{ بيماران سرطان مثانه (V نفر ) } \\
\hline خير & I & خير & $4 q$ & 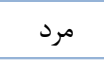 & 1 \\
\hline خير & I & 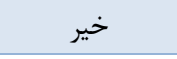 & $\Delta \wedge$ & 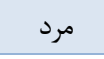 & $r$ \\
\hline خير & II & خير & 9. & زن - ان & $r$ \\
\hline خير & I & بله & rq & مرد & r \\
\hline خير & I & بله & fr & مرد & $\Delta$ \\
\hline خير & I & خير & $\Delta \cdot$ & 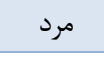 & 9 \\
\hline خير & I & بله & $i \Delta$ & زن - ان & $v$ \\
\hline
\end{tabular}

انجام شد. سيس سلولهاى تك هستهاى خون محيطى توسط يك

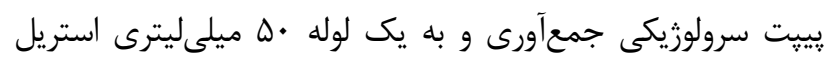

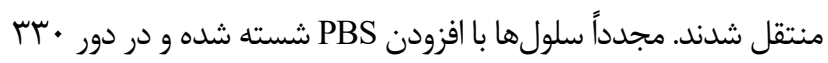

$$
\text { به مدت • ا دقيقه سانتريفيوز گرديدند (19). }
$$

كشت سلولهاى تكهستهاى خون محيطى بيماران

$$
\text { سرطانى و كروه كنترل سالم }
$$

. . ميكروليتر از سلولهاى تكهستهاى خون محيطى جداشده

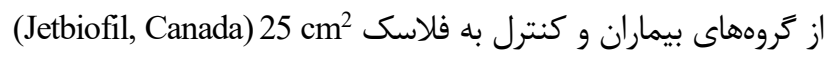

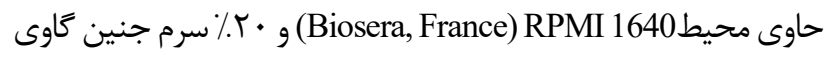

جداسازى سلولهاى تكهستهاى خون محيطى از

$$
\text { بيماران سرطانى و تروه كنترل سالم سلم تكاري }
$$

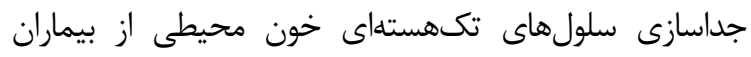
سرطانى و نمونه كنترل سالم با استفاده از روش شيب ترائ تراديان فيكول

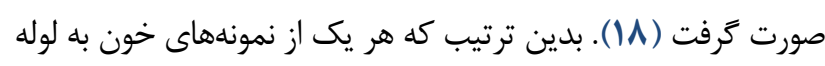

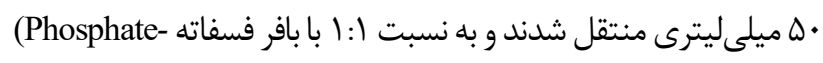
رقيق كرديدند. (Merck, Germany) buffered saline, PBS) (Inno-Train, نمونهاى خون رقيق شده به آرامى به فيكولن

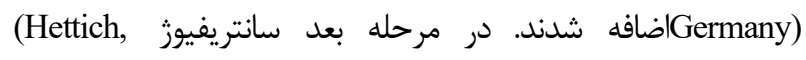

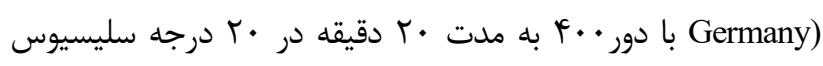


قرار گرفتند و مابقى سلولها بدون تيمار باقى ماندند. سيس

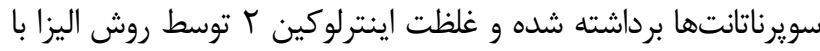
استفاده از كيت تجارى IL-2 انسانى Thermo Fisher ELISA) Scientific, Australia)

\section{تجزيه و تحليل دادهها}

ترشح اينترلوكين T از سلولهاى تهار تيمار و غيرتيمار با بيوسيانين

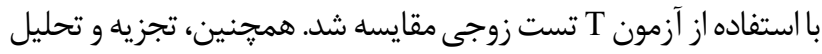

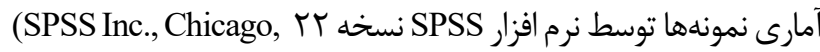

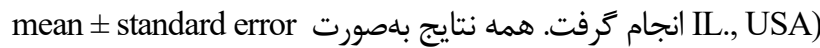
بيان شدند. مقدار P-value كمتر از هـ • إز نظر آمارى معنادار در نظر زرفته شد.

بافتهها

\section{انتخاب ايزوله توليد كننده پييوسيانين با بالاترين غلظت} ايزوله || (از منبع زخم) بالاترين توليد كننده بيوسيانين

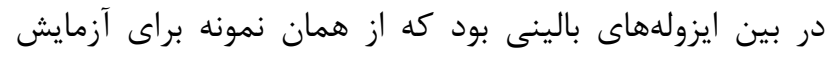

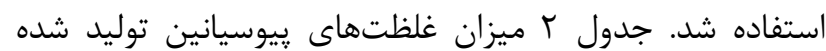

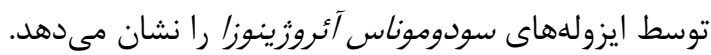

(Fetal bovine serum, FBS) (Biosera, France)

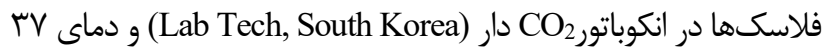

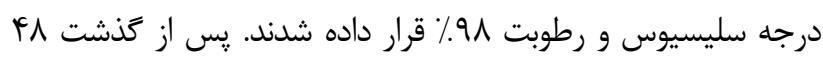
ساعت محيط كشت تعويض گرديد و سلولها باساز داده شدند (•r). براى برداشت سلولهاى متصل به كف فلاسك، محيط كشت به طور

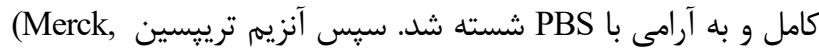
بله فلاسك اضافه كرده و به مدت ه- Germany) YrV درجه سليسيوس قرار كرفت. سلولهاى جدا شده از كف فلاسك به يك لوله استريل ها ميلىليترى منتقل شدند. لوله حاوى سلولها به

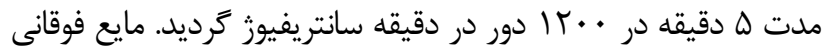

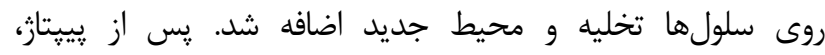
سوسيانسيون سلولى به جند فلاسك جديد بر حسب تراكم سلولى لَّلى

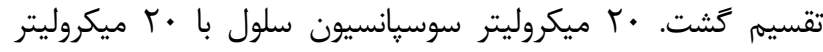

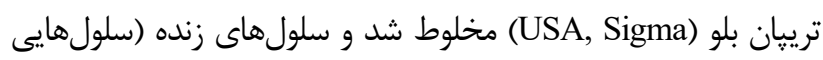

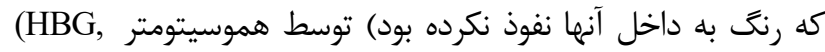
(r+Germany)

اثر يِيوسيانين بر ترشح IL-2 از سلولهاى تكهستهاى خون محيطى در بيماران سرطانى و گروه كنترل نيمى از سلولهاى تكهستهاى خون محيطى بيماران سرطانى و

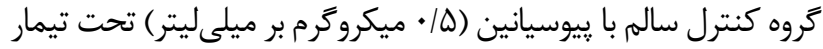

جدول r. غلظتهاى بِيكَمان پييوسيانين توسط ايزولههاى بالينى سودوموناس آئروزينوزا

\begin{tabular}{|c|c|c|c|c|c|c|}
\hline غلظت بيوسيانين (رg/mL) & جذب نورى & بخش & سن & جنسيت & منبع & ايزوله \\
\hline$r / 41$ & $\cdot \pi$. & داخلى ل & $r \Delta$ & زن & ادرار & 1 \\
\hline r/TF & .119 & 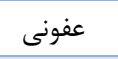 & Gr & 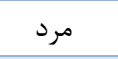 & ادرار & $r$ \\
\hline $1 / \pi 4$ & $\cdot 1 \cdot 1$ & جراحى & $\Delta 1$ & 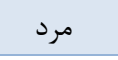 & زخم & $r$ \\
\hline V/IV & . ATt & ICU & vr & زن & 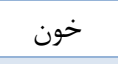 & f \\
\hline $1 / v$ & .11 & عفونى & $\Delta \varphi$ & مرد & ادرار & $\Delta$ \\
\hline$r / 9$. &.$/ 1 \mathrm{~V}$ & 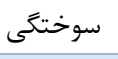 & pr & زن - - ان & سوختىى & 8 \\
\hline$r / \Delta \Lambda$ & $\cdot|r|$ & سوختى & TF & 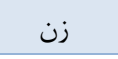 & سوختىى & $v$ \\
\hline$r / 9$. & $\cdot / 4 V$ & ICU & $\Delta \varphi$ & 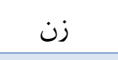 & خون & $\wedge$ \\
\hline$\Delta / \Lambda$. & $\cdot / \mu F$ & جراحى & rı & 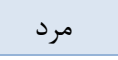 & خون & 9 \\
\hline$r / T F$ & .119 & داخلى & rt & 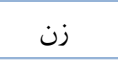 & 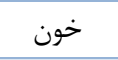 & 1. \\
\hline १/9. & $\cdot 101$ & جراحى & $v \Delta$ & 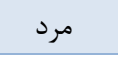 & زخم & 11 \\
\hline $1 / \cdot r$ & .1 .9 & ICU & rq & 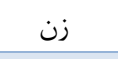 & ادرار & ir \\
\hline$r / 41$ & $\cdot \pi$. & داخلى & $\Delta \wedge$ & 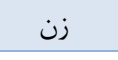 & ادرار & ir \\
\hline$V / \wedge \Delta$ & $\cdot / 48$ & داخلى & $r \Lambda$ & مرد & خون & If \\
\hline $9 / \Gamma \wedge$ & $\cdot 1 \Delta \Delta$ & سوختىى & iv & مرد & سوختكى & 10 \\
\hline
\end{tabular}




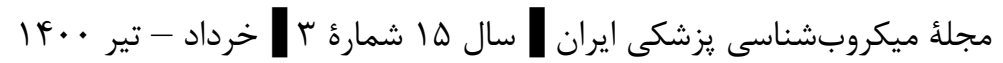

\begin{tabular}{|c|c|c|c|c|c|c|}
\hline غلظت بيوسيانين (رg/mL) & جذب نورى & بخش & سن & جنسيت & منبع & ايزوله \\
\hline$\Delta / / T$ & $\cdot \pi$ & 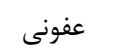 & $a^{\mu}$ & 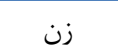 & ادرار & 18 \\
\hline $1 / 19$ & $\cdot / \cdot V$ & عفونى & $r \wedge$ & زن - ان & خلط & iv \\
\hline $1 / \Delta r$ & .1 .9 & 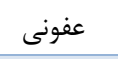 & iv & 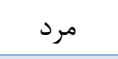 & زخم & 11 \\
\hline D/ब & rז/. & 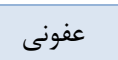 & $r$. & زن & 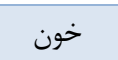 & 19 \\
\hline gINT & $\cdot / 4$ & عفونى & \&9 & مرد & ادرار & r. \\
\hline $1 / 19$ & $\cdot / \cdot V$ & عفونى & rt & 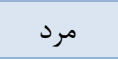 & ادرار & rI \\
\hline V/91 & $\cdot / 4 \Delta$ & 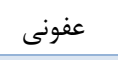 & $r r$ & 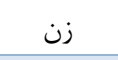 & خون & rr \\
\hline$r / 9$. &.$/ 1 \mathrm{~V}$ & ICU & $\vee$. & 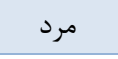 & خون & rr \\
\hline $1 / \pi 4$ & $\cdot 1 \cdot 1$ & 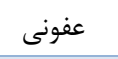 & $\Delta r$ & 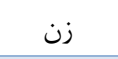 & ادرار & rF \\
\hline $1 / \Delta r$ & .1 .9 & 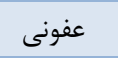 & is & زن & خلط & ra \\
\hline$V / \wedge \Delta$ & $\cdot / 49$ & سوختى & $\Delta r$ & مرد & سوختىى & rq \\
\hline 9190 & $\cdot / 49$ & 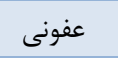 & rV & 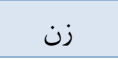 & ادرار & rV \\
\hline Q/q & 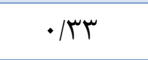 & 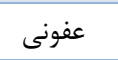 & rq & مرد & خلط & rA \\
\hline$T / T)$ &.$/ 1 r$ & عفونى & rq & زن & خون & rq \\
\hline$V / 9 \Lambda$ & $\cdot / 4 \Delta$ & داخلى & re & مرد & ادرار & $r$. \\
\hline
\end{tabular}

نمونههاى كنترل سالم (V) نفر) قبل و بعد از تيمار با رنكدانه

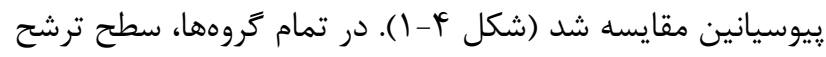

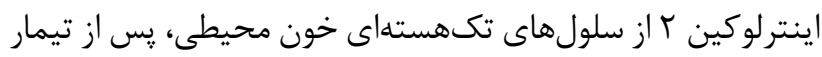

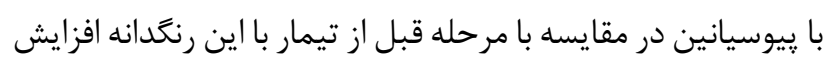
يافته بود.
مقايسه ترشح اينترلوكين r از سلولهاى تكهستهاى

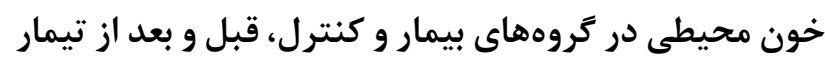
با بيوسيانين با روش اليزا، ميزان ترشح اينترلوكين r از سلولهاى تكهستهاى خون محيطى در بيماران مبتلا به سرطان ( آ نفر ) و

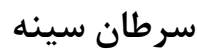

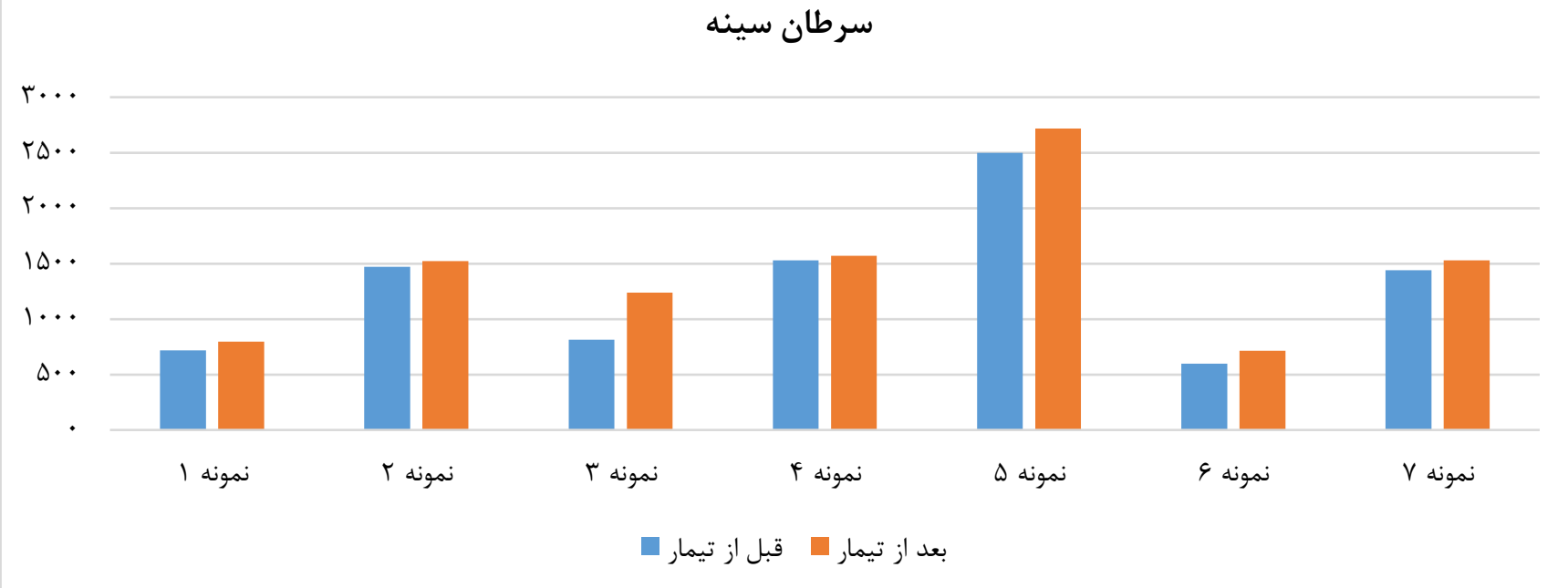




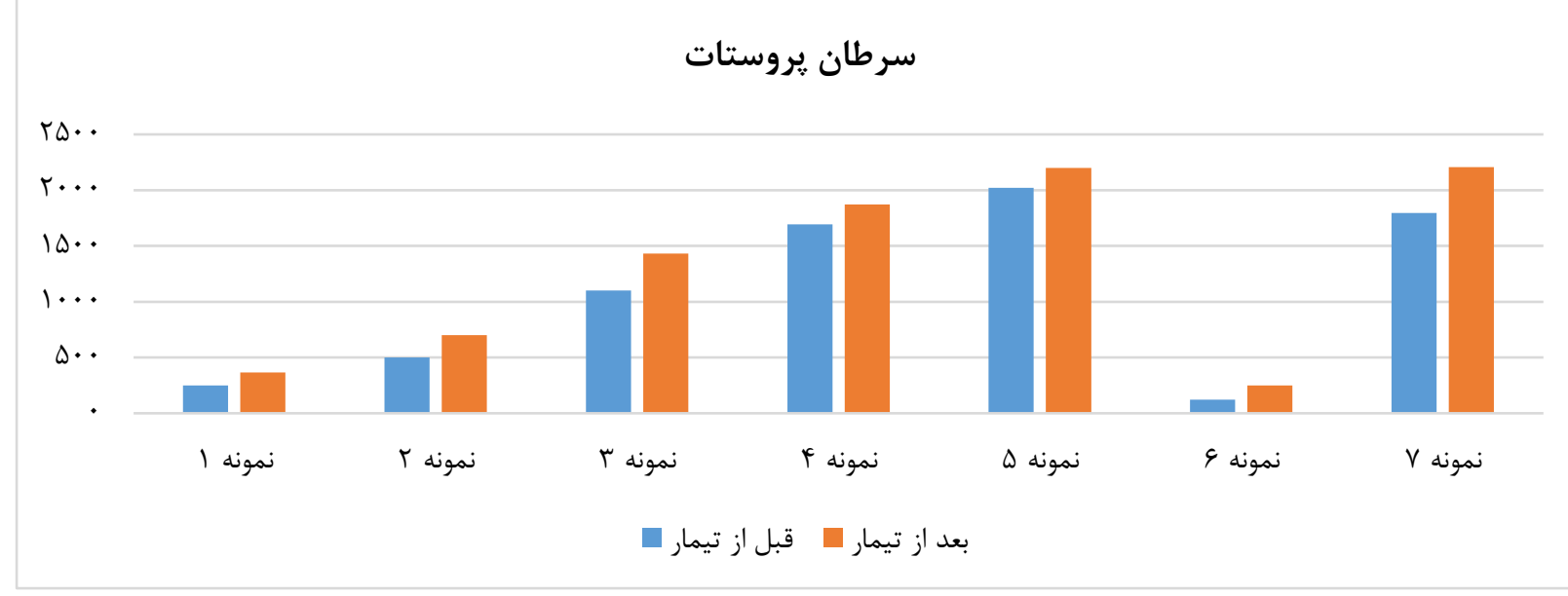

شكل r. ميزان غلظت اينترلوكين r، قبل و بعد از تيمار با پٍيگمان پييوسيانين در نمونههاى سرطان يروستات

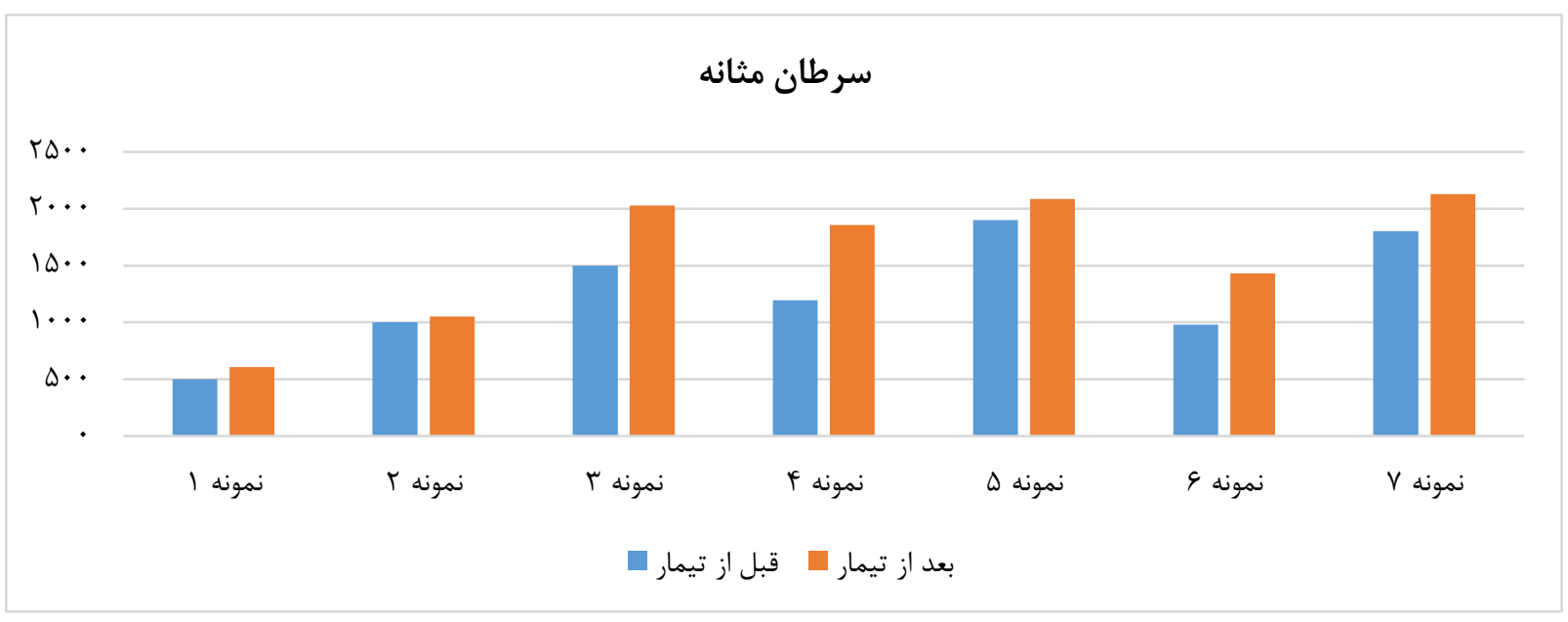

شكل r. ميزان غلظت اينترلوكين r، قبل و بعد از تيمار با پيخمان پيوسيانين در نمونههاى سرطان مثانه

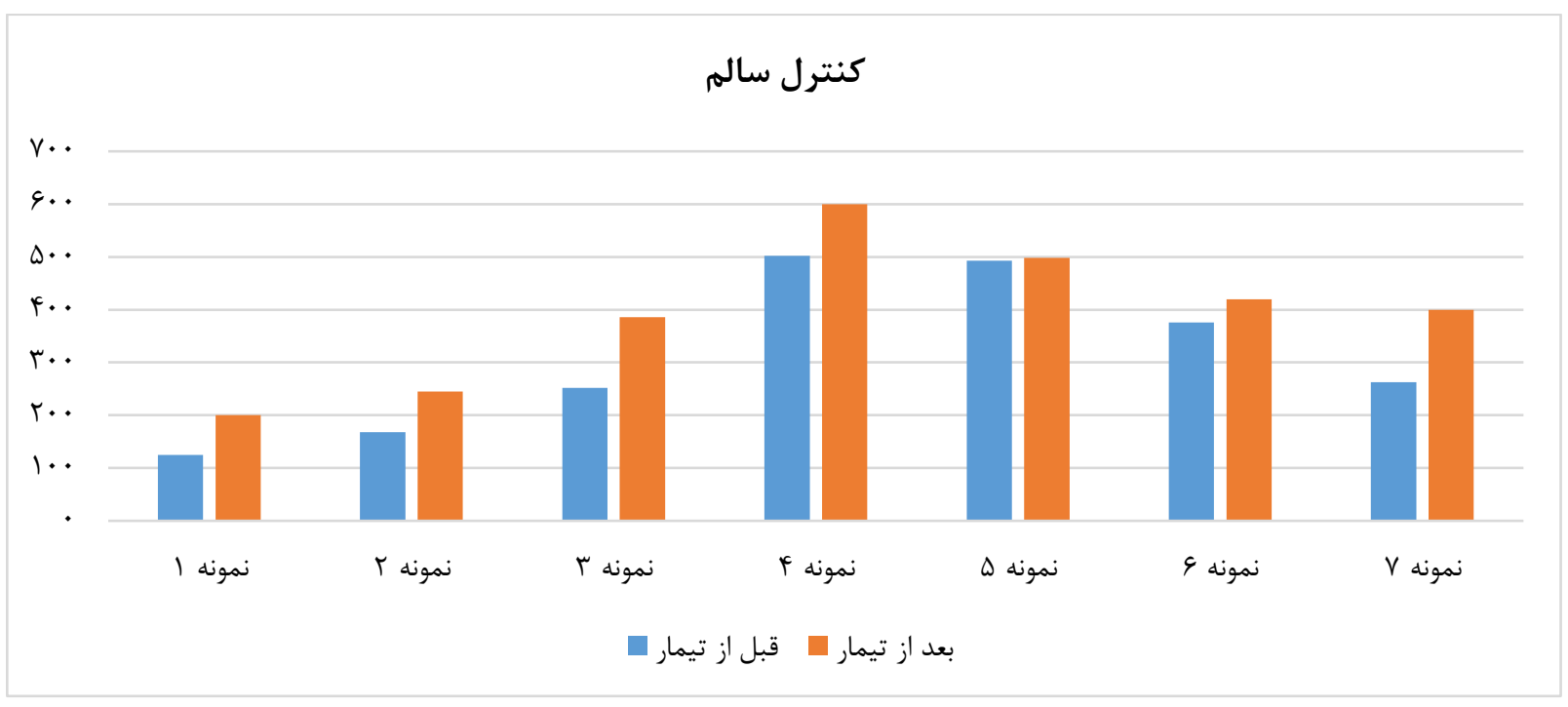

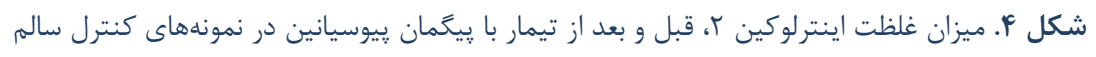


با قبل از تيمار با اين ربكاندانه با ميانكين

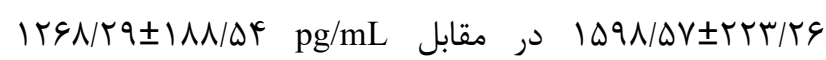

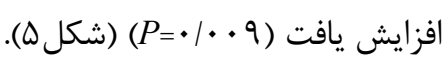
ترشح IL-2 از سلولهاى تكهستهاى خون محيطى افراد كنترل

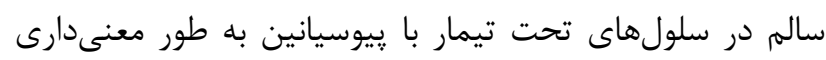

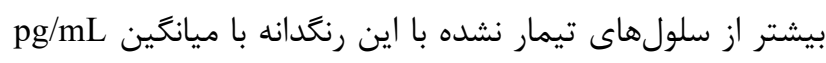

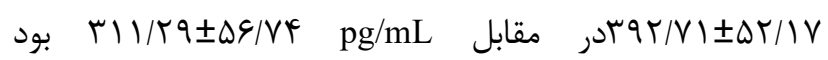
(شكله) ( $(P=\cdot / \cdot r)$ بنابراين، افزايش غلظت IL-2 يس از تيمار با بيوسيانين در

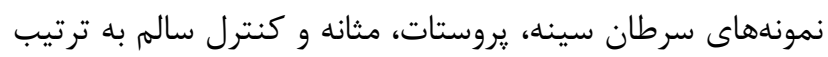

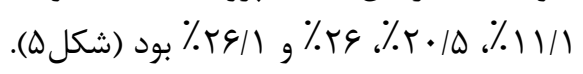

ترشح IL-2 از سلولهاى تكهستهاى خون محيطى در بيماران

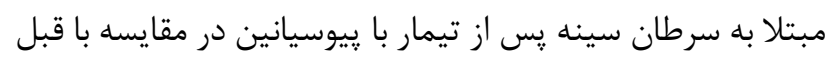

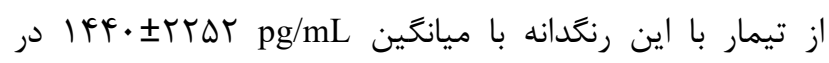

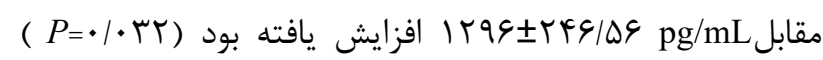
(شكله). ترشح IL-2 از سلولهاى تكهستهاى خون محيطى بيماران مبتلا

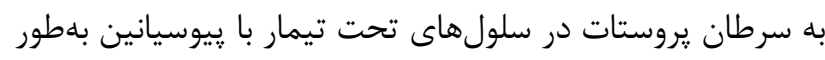

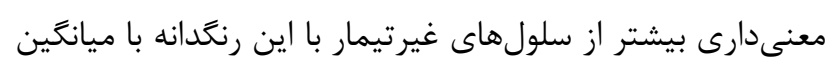

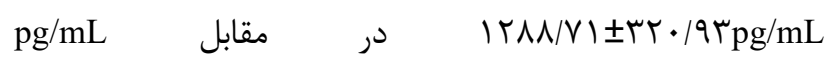

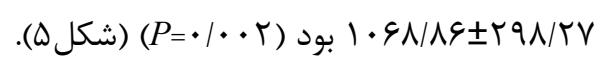
سطح ترشح IL-2 از سلولهاى تكهستهاى خون محيطى در

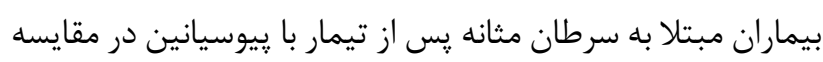

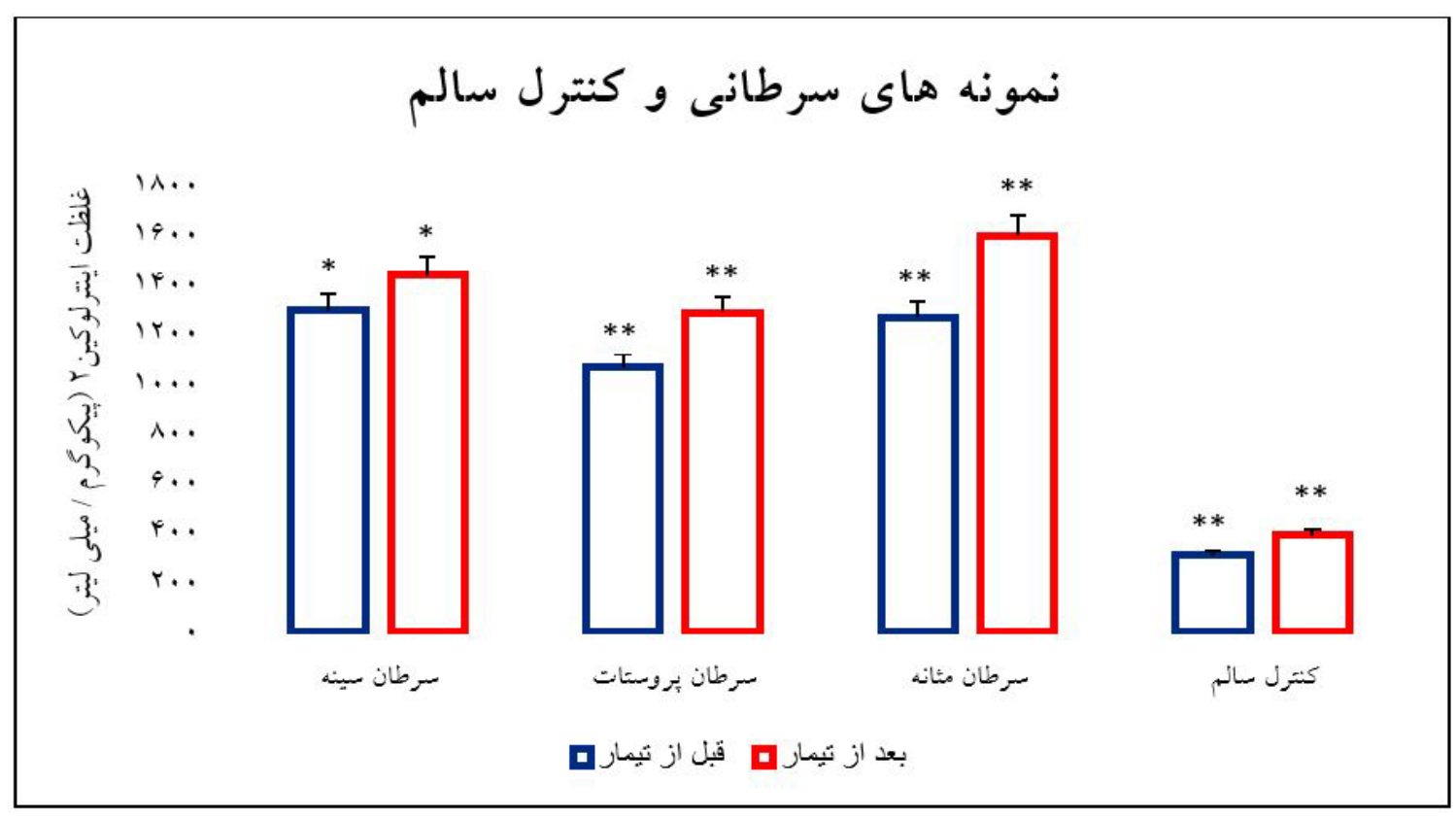

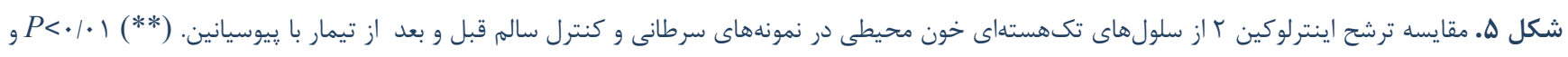
$P<\cdot / \cdot \Delta\left({ }^{*}\right)$

براساس نتايج اين مطالعه، غلظت كم يُوسيانين سبب

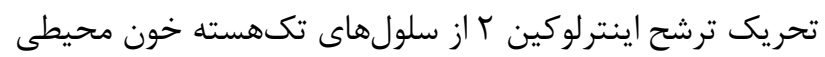

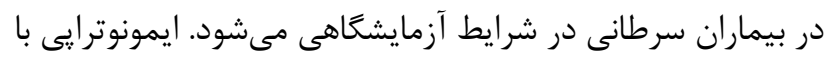

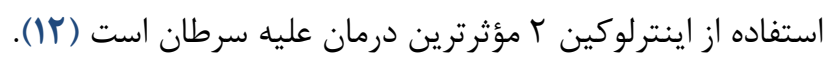

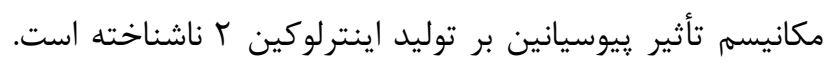

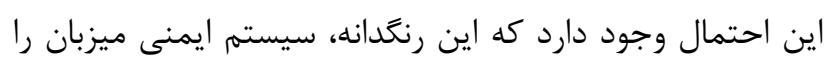

رنحدانههاى باكتريايى با آزادسازى سيتوكينها در بيماران

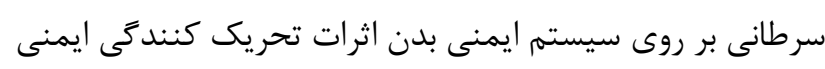

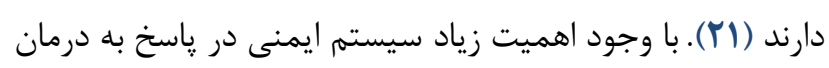

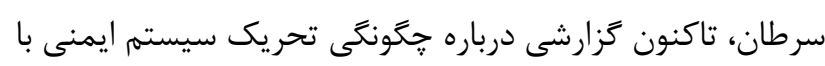

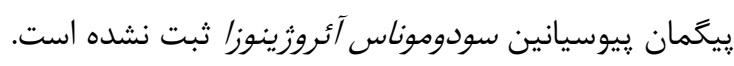




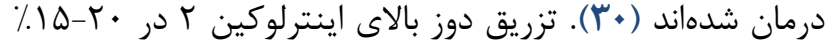

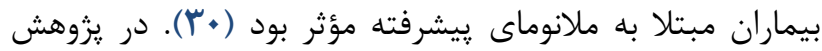

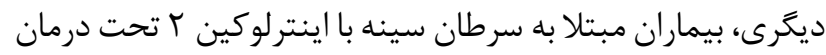

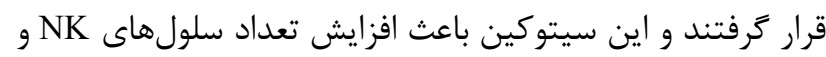
عملكرد ليز سلولى در بدن گرديد (Yq). طى تحقيقى Freytag و

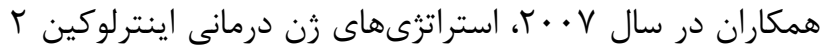

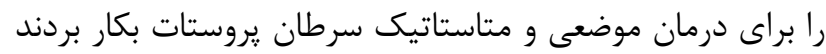

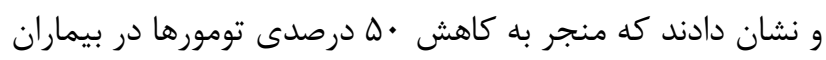

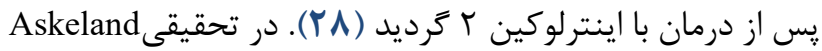

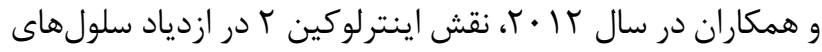
كشنده طبيعى در بيماران مبتلا به سرطان مثان مثانه و ونتيجه

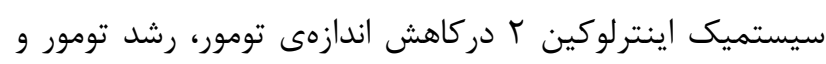
طول مدت زنده ماندن بيماران سرطانى را بررسى نمودند (YV).

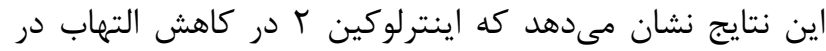
محيط تومور نقش بسزايى داشته و در يك دوره منظهم مى تواند

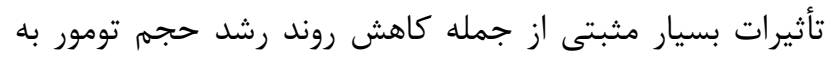

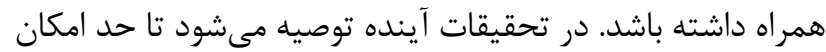
اندازه جامعه آمارى افزايش يابد.

\section{نتيجلمَيرى}

نتايج اين مطالعه نشان داد رنحَدانه ييوسيانين سبب افزايش ترشح غلظت اينترلوكين r توسط سلولهاى تك هسته خون محيطى در بيماران مبتلا به سرطان سينه، يروستات، مثانه و افراد

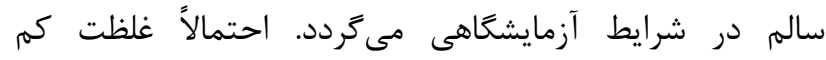

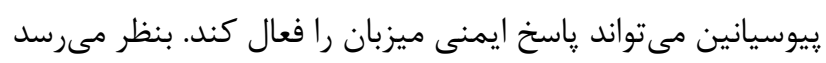
اين رنكدانه از طريق فعاليت مسير سيخنالدهى گيرندههاى شبه

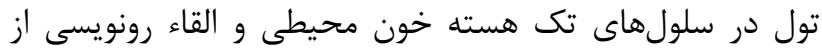

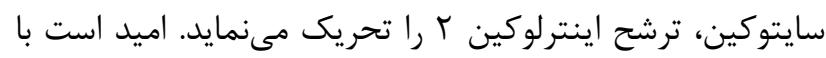

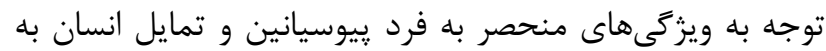
درمانهاى بيولوزيك و كم خطر، دانش ايمونوبيولوزى در زمينه

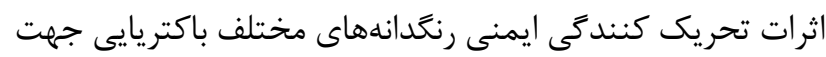

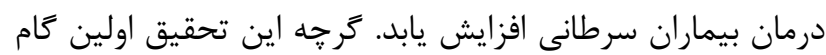
در شناسايى اثرات تحريك كنندگى ايمنى رنكدانه در شرايط

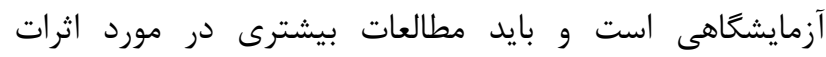

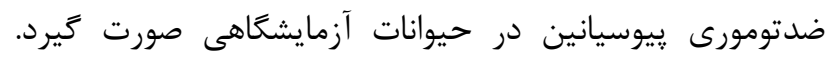
همجنين، تلاشهاى زيادى به منظور تشخيص مكانيسم عملكرد اين پِيگمان در تحريك سلولهاى تكهسته خون محيطى در

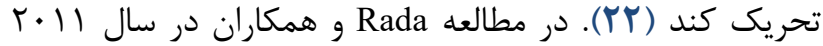
مشخص شد كه يِيوسيانين رونويسى از سيتوكينهاى التهابى و

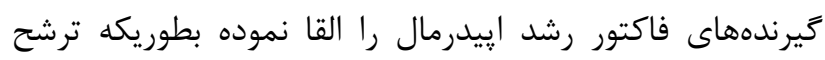
سيتو كينهاى اينترلوكين ا، اينترلوكين و، اينترلوكين ^و و فاكتور

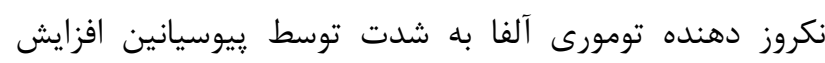

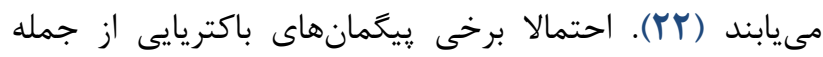

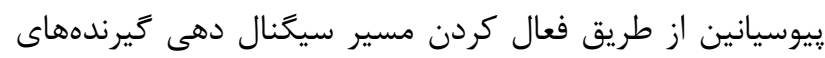
شبه تول (Toll like receptors, TLRs) در سلولهاى تك هسته خون محيطى سبب تحريك ترشح سيتوكينها از جمله اينترلوكين

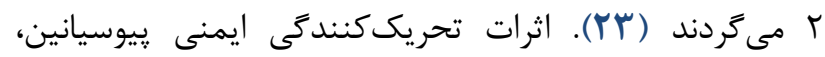

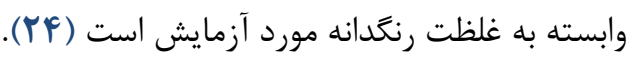

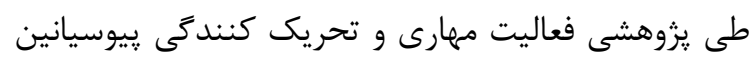

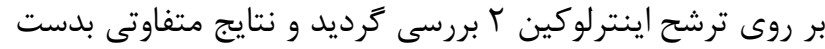

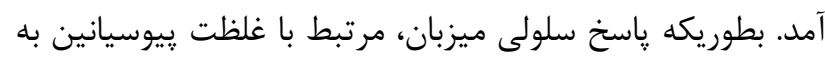

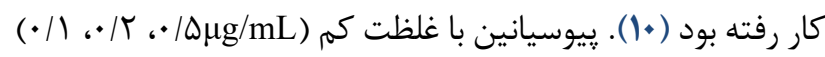

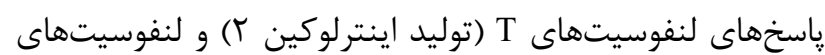

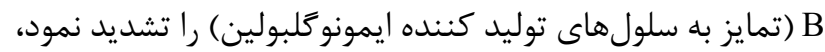

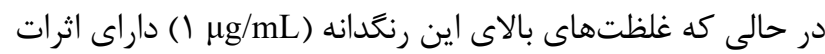

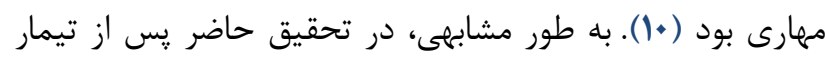

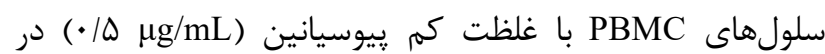
بيماران مبتلا به سرطانهاى سينه، يروستات و مثانه، افزايش

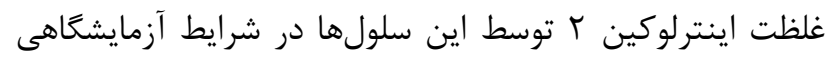

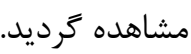

اينترلوكين T فعال كننده سلولهاى T سيتوتوكسيك

(CTL) و سلولهاى كشنده طبيعى (NK cells) است (•). سلولهاى NK سلولهاى هدف را با ترشح كرانولهاى آنها

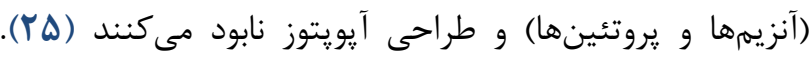

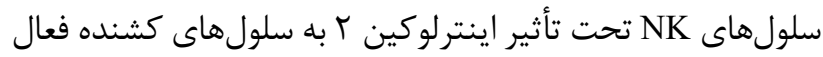
لنفوكين (lymphokine-activating killer cells, LAK cells) تبديل مىشوند (ها). فعاليت سيتوليتيك سلولهاى LAK عليه

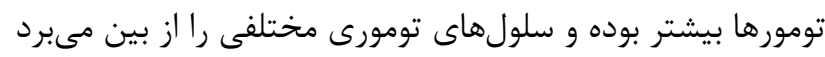

در مطالعات مرتبط با نقش اينترلوكين ؟ در درمان سرطان، تحقيقات مشابهى در زمينه اثرات مثبت اينترلوكين r در درمان بيماران مبتلا به سرطانهاى كليه، سينه، يروستات و مثانه انجام شده است (•r-Yצ). به طورى كه طبق تحقيقات صورت كرفته،

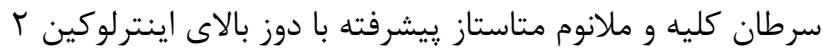




$$
\begin{aligned}
& \text { تعارض در منافع } \\
& \text { اين مقاله يزوهشى مستقل است كه بدون حمايت مالى } \\
& \text { سازمانى انجام شده است .در انجام مطالعأه حاضر، نويسندكان } \\
& \text { هيجگَونه تضاد منافعى نداشتهاند. }
\end{aligned}
$$

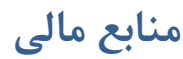

$$
\begin{aligned}
& \text { ندارد. }
\end{aligned}
$$

\section{Referance}

1. Knox SS. From omics to complex disease: a systems biology approach to gene-environment interactions in cancer. Cancer Cell Int. 2010;10:11. [DOI:10.1186/1475-2867-10-11] [PMID] [PMCID]

2. Noori Daloii MR, Sadr Z. Cancer immunotherapy: Use the immune system to fight cancer. J Sabzevar Uni Med Sci. 2020;26(1):1-11.

3. Marrazzo E, Frusone F, Milana F, Sagona A, Gatzemeier W, Barbieri E, et al. Mucinous breast cancer: A narrative review of the literature and a retrospective tertiary single cancer analysis. Breast. 2020;49:87-92. [DOI:10.1016/j.breast.2019.11.002 [DOI:10.1016/j.breast.2019.11.002] [PMCID]

[PMID]

4. Pakzad R, Rafiemanesh H, Ghoncheh M, Sarmad A, Salehiniya H, Hosseini S, et al. Prostate cancer in Iran: trends in incidence and morphological and epidemiological characteristics. Asian Pac J Cancer Prev. 2016;17(2):839-43. [DOI:10.7314/APJCP.2016.17.2.839] [PMID]

5. Farhood B, Geraily G, Alizadeh A. Incidence and mortality of various cancers in Iran and compare to other countries: a review article. Iran J Public Health. 2018;47(3):309-16.

6. Rezaianzadeh A, Mohammadbeigi A, Moballeghi J, Mohammadsalehi N. Survival analysis of patients with bladder cancer, life table approach. J Midlife Health. 2012;3(2):88-92. [DOI:10.4103/09767800.104468] [DOI:10.4103/0976-7800.104468]

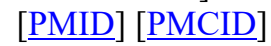

7. Song S, Vuai MS, Zhong M. The role of bacteria in cancer therapy - enemies in the past, but allies at present. Infect Agent Cancer. 2018;13:9. [DOI:10.1186/s13027-018-0180-y]

[PMID] [PMCID]

8. El-Fouly MZ, Sharaf AM, Shahin AAM, El-Bialy HA, Omara AMA. Biosynthesis of pyocyanin pigment by Pseudomonas aeruginosa. J Radiat Res Appl Sci. 2015;8(1):36-48. [DOI:10.1016/j.jrras.2014.10.007]

$$
\begin{aligned}
& \text { بيماران سرطانى جهت ترشح سايتوكين ضدسرطانى اينترلوكين } \\
& \text { مورد نياز است. }
\end{aligned}
$$

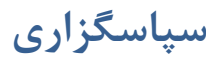

$$
\begin{aligned}
& \text { اين يروهش بركرفته از پايان نامه دانشجويى كارشناسى ارشد } \\
& \text { ميكروبيولوزى دانشگاه آزاد اسلامى واحد كازرون است. از تمام } \\
& \text { كسانى كه ما را در انجام اين تحقيق يارى نمودند قدردانى مى گردد. }
\end{aligned}
$$

9. Zhao J, Wu Y, Alfred AT, Wei P, Yang S. Anticancer effects of pyocyanin on HepG2 human hepatoma cells. Lett Appl Microbiol. 2014;58(6):541-8. [DOI:10.1111/lam.12224] [PMID]

10. Ulmer AJ, Pryjma J, Tarnok Z, Ernst M, Flad HD. Inhibitory and stimulatory effects of Pseudomonas aeruginosa pyocyanin on human $\mathrm{T}$ and $\mathrm{B}$ lymphocytes and human monocytes. Infect Immun. 1990;58(3):808-15. [DOI:10.1128/iai.58.3.808815.1990] [피] [PMCID]

11. Lissoni P. Therapy implications of the role of Interleukin-2 in cancer. Expert Rev Clin Immunol. 2017;13(5):491-8. [DOI:10.1080/1744666X.2017.1245146] [PMID]

12. Choudhry H, Helmi N, Abdulaal WH, Zeyadi M, Zamzami MA, Wu W, et al. Prospects of IL-2 in cancer immunotherapy. Biomed Res Int. 2018;2018:9056173. [DOI:10.1155/2018/9056173] [PMID] [플

13. Setrerrahmane $\mathrm{S}, \mathrm{Xu} \mathrm{H}$. Tumor-related interleukins: old validated targets for new anti-cancer drug development. Mol Cancer. 2017;16(1):153. [DOI:10.1186/s12943-017-0721-9] [PMID] [PMCID]

14. Holt JG, Krieg NG, Sneathm PHA, Staley JT, Williams ST. Bergey's Manual of Determinative Bacteriology. 9th ed. Baltimore: Williams \& Wilkins; 1994. 206-8.

15. Pang Z, Raudonis R, Glick BR, Lin TJ, Cheng Z. Antibiotic resistance in Pseudomonas aeruginosa: mechanisms and alternative therapeutic strategies. Biotechnol Adv. 2019;37(1):177-92. [DOI:10.1016/j.biotechadv.2018.11.013] [PMID]

16. Moayedi A, Nowroozi J, Akhavan Sepahi A. Cytotoxic effect of pyocyanin on human pancreatic cancer cell line. Iran J Basic Med Sci. 2018;21(8-) : 794-9. 
17. Priyaja P, Jayesh P, Philip R, Bright Singh IS. Pyocyanin induced in vitro oxidative damage and its toxicity level in human, fish and insect cell lines for its selective biological applications. Cytotechnology. 2016;68(1):143-55. [DOI:10.1007/s10616-014-

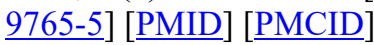

18. Dieter C, Dutra Lourenco E, Emerim Lemos N. Association of long non-coding RNA and leukemia:a systematic review. Gene. 2020;735:144405. [DOI:10.1016/j.gene.2020.144405] [PMID]

19. Weckle A, Aiello AE, Uddin M, Galea S, Coulborn $\mathrm{RM}$, Soliven R, et al. Rapid fractionation and isolation of whole blood components in samples obtained from a community-based setting. J Vis Exp. 2015;(105):52227. [DOI:10.3791/52227] [PMID] [PMCID]

20. Piccinini F, Tesei A, Arienti C, Bevilacqua A. Cell counting and viability assessment of $2 \mathrm{D}$ and $3 \mathrm{D}$ cell cultures: expected reliability of the trypan blue assay. Biol Proced Online. 2017;19(1):8. [DOI:10.1186/s12575-017-0056-3] [PMID] [PMCID]

21. Shahbazi S, Abolhasani A. Immunostimulants: types and functions. J Med Microbiol Infec Dis. 2016;4(34):45-51. [URL:http://jommid.pasteur.ac.ir/article-1131-en.htm]

22. Rada B, Gardina P, Myers TG, Leto TL. Reactive oxygen species mediate inflammatory cytokine release and EGFR-dependent mucin secretion in airway epithelial cells exposed to Pseudomonas pyocyanin. Mucosal Immunol. 2011;4(2):158-71. [DOI:10.1038/mi.2010.62] [PMID] [PMCID]

23. Venegas FA, Köllisch G, Mark K, Diederich WE, Kaufmann A, Bauer S, Chavarría M, Araya JJ, García-Piñeres AJ. The bacterial product violacein exerts an immunostimulatory effect via TLR8. Sci
Rep. 2019; 9(1):13661. [DOI:10.1038/s41598-019-

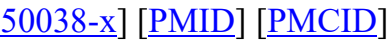

24. Azman AS, Mawang CI, Abubakar S. Bacterial Pigments: The bioactivities and as an blternative for therapeutic applications. Nat Prod Commun. 2018;13(12):1747-54

[DOI:10.1177/1934578X1801301240]

25. Rosenberg SA. IL-2: The first effective immunotherapy for human cancer. J Immunol. 2014;192(12):5451-8.

[DOI:10.4049/jimmunol.1490019] [PMCID]

26. Antony GK, Dudek AZ. Interleukin 2 in cancer therapy. Curr Med Chem. 2010;17(29):3297-302. [DOI:10.2174/092986710793176410] [PMID]

27. Askeland EJ, Newton MR, O'Donnell MA, Luo Y. Bladder cancer immunotherapy: BCG and beyond. Adv Urol. 2012;2012:181987. [DOI:10.1155/2012/181987] [PMID] [PMCID]

28. Freytag SO, Stricker H, Movsas B, Kim JH. Prostate cancer gene therapy clinical trials. Mol Ther. 2007;15(6):1042-52. [DOI:10.1038/sj.mt.6300162] [PMID]

29. Repka T, Chiorean E, Gay J, Herwig K, Kohl K, Yee D, et al. Trastuzumab and Interleukin-2 in HER2positive metastatic breast cancer: a pilot study. Clin Cancer Res. 2003;9(7):2440-6.

30. Ridolfi L, de Rosa F, Ridolfi R, Gentili G, Valmorri L, Scarpi E, et al. Radiotherapy as an immunological booster in patients with metastatic melanoma or renal cell carcinoma treated with high-dose Interleukin-2: evaluation of biomarkers of immunologic and therapeutic response. J Transl Med. 2014;12:262. [DOI:10.1186/s12967-014-0262-6]

[PMID] [PMCID] 